\title{
Footprints of palaeocurrents in sedimentary sequences of the Cenozoic across the Maurice Ewing Bank
}

\author{
Banafsheh Najjarifarizhendi *, Gabriele Uenzelmann-Neben \\ Alfred-Wegener-Institute für Polar- und Meeresforschung, Am Alten Hafen 26, 27568 Bremerhaven, Germany
}

\section{A R T I C L E I N F O}

Editor: Michele Rebesco

\section{Keywords:}

Falkland/Malvinas Plateau

South Atlantic

Seismic reflection data

DSDP Leg 36 and 71

Sediment drifts

Oceanic currents

\begin{abstract}
A B S T R A C T
High-resolution seismic reflection data across the Maurice Ewing Bank, the easternmost section of the Falkland/ Malvinas Plateau in the SW South Atlantic, is integrated with information from Deep Sea Drilling Project Leg 36, Sites 327, 329, and 330 and Leg 71 Site 511. Five seismic units were identified ranging in age from the middle Jurassic to Quaternary and are interpreted with respect to the evolution of the oceanic circulation in the Atlantic sector of the Southern Ocean in response to tectonic and climatic events. Sedimentary sequences of late Cretaceous and early Paleogene include little and restricted evidence of current activity, attributable to shallow/ intermediate-depth connections between the developing South Atlantic and the Southern Ocean. In contrast, sedimentary sequences of the late Eocene/Oligocene and Neogene reveal a history of strong current-related erosion and deposition. These features are identified in specific water-depth ranges and interpreted to document proto-Upper and -Lower Circumpolar Deep Waters to have shaped the bank since the Oligocene. The Maurice Ewing Bank bathymetric high thus has been acting as a barrier for the deep and bottom water masses flowing within the Antarctic Circumpolar Current since its establishment at the Eocene-Oligocene boundary. This study provides evidence for a multi-layered ocean already in the Paleocene/early Eocene.
\end{abstract}

\section{Introduction}

In the present oceanic regime, the western South Atlantic forms a crucial gateway for the exchange of water masses between the Southern Ocean, South Pacific, and the South Atlantic; where the circulation is controlled by the complex topography of the Drake Passage and the Scotia Sea (Fig. 1a). As a pronounced bathymetric high, the Maurice Ewing Bank (MEB), the easternmost extremity of the Falkland/Malvinas Plateau (F/MP), steers the deep and bottom water masses flowing within the Antarctic Circumpolar Current (ACC). On their journey around the bathymetric obstacles, the oceanic currents undergo acceleration and disruption, leaving behind erosional and depositional features. The socalled contourite drifts form an archive of pathways and intensities of the palaeocirculation, which are in turn controlled by tectonic movements and climate modifications (Rebesco et al., 2007; Rebesco et al., 2014; Stow et al., 2002). Seismic reflection imaging allows studying of the modifications of the palaeocurrents' pathways and intensification through interpretation of the spatial distribution, morphological and structural characteristics of observed contourite drifts.

So far, the area south and east of the Falkland/Malvinas Islands and further west towards South America has been the subject of a number of studies (Koenitz et al., 2008; Nicholson and Stow, 2019; Pérez et al., 2015), but the available seismic reflection data across the MEB is sparse and yet low-resolution (Ciesielski and Weaver, 1980; Shipboard Scientific Party, 1977). So, little is known about the location and re-location of the water masses flowing within the ACC in the southwestern South Atlantic since the onset of Antarctica's glaciation at the EoceneOligocene boundary, which in turn has had a significant influence on climate.

We present newly collected high-resolution multichannel seismic reflection data across the MEB, acquired during RV Maria S. Merian expedition MSM81 in early 2019, including a direct crossing of the Deep Sea Drilling Project (DSDP) Leg 36 Sites 327, 329, and 330 and Leg 71 Site 511 (Fig. 1b). Drilling data from the DSDP boreholes are incorporated into the study to transfer the chronostratigraphic model into a seismostratigraphic model used for a qualitative seismic interpretation across the bank. The geometry of the identified current-related depositional and erosional features observed on the seismic profiles are mapped and translated into spatiotemporal variations of the palaeocurrents. We identify and interpret depositional and erosional features across the

\footnotetext{
* Corresponding author.

E-mail address: banafsheh.najjarifarizhendi@awi.de (B. Najjarifarizhendi).
} 
MEB in pursuit of understanding the evolution of the regional oceanic settings in response to tectonic and climatic events.

\section{Geological and oceanographic background}

The F/MP can be subdivided into three distinct provinces of the Falkland/Malvinas Islands, the Falkland/Malvinas Plateau Basin, and the Maurice Ewing Bank (MEB) (e.g., Lorenzo and Mutter, 1988; Shipboard Scientific Party, 1974a, 1974c, 1974d, 1980a). The MEB constitutes the morphostructural elevated easternmost part of the plateau, located on the westernmost part of the Agulhas-Falkland Fracture zone in the southwestern Atlantic Ocean (Fig. 1b). The MEB rises about 1500 $\mathrm{m}$ above the surrounding seafloor and has formed a barrier for the oceanic circulation since the separation of South America and Africa.

Although drilling into the gneissose and granitic basement at DSDP Leg 36 Site 330 on the western shoulder (the area between the MEB and the Falkland/Malvinas Basin) of the MEB has attested to the continental origin of this part (Shipboard Scientific Party, 1974d), there remains ambiguity as to the nature of the plateau's underlying crust. Three prevailing schemes exist for the paleogeography of the Falkland/ Malvinas Islands microplate prior to the Gondwana breakup. The first explains the present location with a clockwise rotation from its origin southeast of South Africa and drift along the transform faults (e.g., Eagles and Eisermann, 2020; Marshall, 1994; Stone et al., 2009; Taylor and Shaw, 1989; Thomson, 1998). The second suggests a paleo-location between South America and South Africa (Du Toit, 1927; Du Toit,
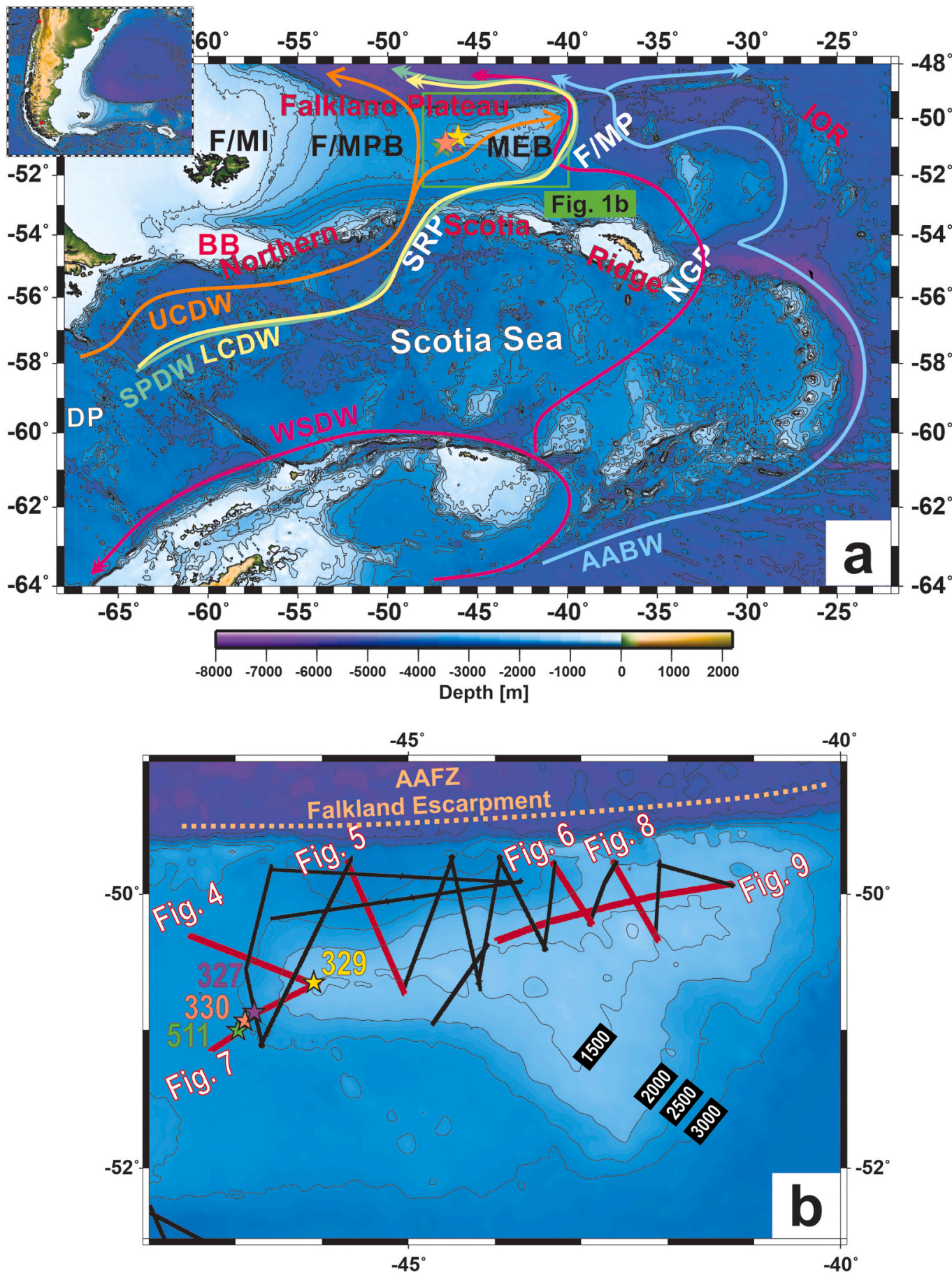

Fig. 1. (a) Bathymetric map of the Falkland/Malvinas Plateau and western South Atlantic sector of the Southern Ocean (Smith and Sandwell, 1997). Arrows schematically show the pathways of the southern-sourced deep/bottom water masses in the present oceanic scheme (Arhan et al., 1999; Arhan et al., 2002; Orsi et al., 1999): Upper Circumpolar Deep Water (UCDW) in orange, Lower Circumpolar Deep Water (LCDW) in yellow, South Pacific Deep Water (SPDW) in green, Weddell Sea Deep Water (WSDW) in pink, and Antarctic Bottomwater (AABW) in blue. $\mathrm{BB}=$ Burdwood Bank; DP = Drake Passage; $\mathrm{FI}=$ Falkland/Malvinas Islands; F/ $\mathrm{MP}=$ Falkland/Malvinas Passage; F/ MPB $=$ Falkland/Malvinas Plateau Basin; IOR = Islas Orcadas Rise; MEB $=$ Maurice Ewing Bank; NGP = North Georgia Passage; SRP $=$ Shag Rocks Passage. The green box indicates the study area shown in Fig. 1b, and stars show the location of the DSDP sites in the study area. (b) Bathymetric map of the Maurice Ewing Bank (Smith and Sandwell, 1997). Superimposed are the locations of the seismic profiles used for the study. Dark red lines illustrate the location of profiles shown in the figures. Stars mark the location of DSDP Leg 36 Sites 327, 329, and 330 and Leg 71, Site 511 in the study area. The dotted line represents the location of the AgulhasFalkland Fracture Zone (AFFZ). (For interpretation of the references to color in this figure legend, the reader is referred to the web version of this article.) 
1937), while the third concludes that the plateau has been a rigid part of the South American plate (Barker, 2001; Borrello, 1963; Chemale Jr et al., 2018; Ramos et al., 2017).

DSDP drillings on the western shoulder of the MEB shed light on the sedimentation history on the F/MP, which includes a primary phase of shallow-water marine setting mainly in the Mesozoic and a second phase of pelagic sedimentation predominantly in the Cenozoic (Timofeev et al., 1980). Following a marine transgression, deposition took place in the middle to late Jurassic in an open shelf environment. Sapropelic claystone of the late Jurassic (mainly Oxfordian) through the Aptian gives evidence for the development under euxinic conditions in a restricted basin subject to sluggish oceanic circulations (Dummann et al., 2020; Shipboard Scientific Party, 1977). Rapid subsidence gave way to open marine conditions starting in Albian and going on through the late Cretaceous and Paleocene (Barker, 1977; Ludwig, 1983; Shipboard Scientific Party, 1974a, 1974d, 1980a; Thompson, 1977). This transition may have resulted from abyssal connections between the Indian and the developing South Atlantic oceans (Barker, 1977; Dingle and Robson, 1992; Dummann et al., 2020; Ludwig, 1983; Shipboard Scientific Party, 1974a, 1974d, 1980a).

A major non-depositional to erosional hiatus across the late Cretaceous to Paleocene, known as the Cretaceous-Tertiary boundary event, is considered to be the product of a poor-carbonate ocean and a shallow Carbonate Compensation Depth (CCD) (Ciesielski and Wise Jr, 1977; Shipboard Scientific Party, 1974a, 1977; Worsley, 1974) as well as the arising changes in the bottom circulation patterns (Barker, 1977; Lorenzo and Mutter, 1988; Ludwig, 1983; Shipboard Scientific Party, 1977). Moreover, at this boundary abrupt biotic changes and a brief earliest Paleocene cooling have been associated with the Chixulub meteorite impact (Brett, 1992; Gulick et al., 2008; Schulte et al., 2010).

Reinforced bottom currents and higher productivity were the leading agents for the post-Eocene sediment accumulation on the MEB (Shipboard Scientific Party, 1974c, 1977). An early to middle Eocene hiatus is assumed to be a consequence of the distant tectonic event of the separation of East Antarctica and Australia (Tasman Gateway), which contributed to the development of a circumpolar current pathway (Shipboard Scientific Party, 1974c). A sudden surge in the bottom currents across the Eocene-Oligocene boundary subsequent to the regional tectonic evolution leading to the opening of the Drake Passage is accounted for the significant scouring and sediment removals throughout the Neogene (e.g., Barker, 1977; Barker and Thomas, 2004; Ciesielski and Wise Jr, 1977; Nicholson and Stow, 2019; Scher and Martin, 2006; Shipboard Scientific Party, 1974a, 1974c, 1974d, 1980a; Uenzelmann-Neben et al., 2017).

Reorganization of the oceanic currents and the establishment of the Antarctic Circumpolar Current (ACC) following the opening of the Southern Ocean gateways prompted the vast glaciations of the Antarctic continent (Ciesielski and Wise Jr, 1977; Katz et al., 2011; Scher et al., 2015). This in turn led to increased Antarctic Bottomwater (AABW) production beneath the expanding Antarctic ice-shelves (Ciesielski and Weaver, 1980). Vigorous deep and bottom water circulation resulted in the most severe erosional event observed in the late Miocene and contributed to the complex erosional history of the MEB (Shipboard Scientific Party, 1974a, 1974c). Based on evidence of ceased carbonate depositions, the Polar Front (PF) is suggested to have moved to the north of the bank in the Miocene, while abyssal currents kept scouring the sediments to shape the mounded MEB (Ciesielski and Wise Jr, 1977). The erosion of the older sediments was impeded by the accumulation of the glacial marine sediments throughout the Plio-Pleistocene, whereas a change towards local Carbonate deposition occurred in the late Pleistocene as the PF migrated to the south of the bank (Ciesielski and Wise Jr, 1977).

As the largest and strongest current system on Earth today contributing to mass and energy exchange in the Southern Ocean, the clockwise flowing ACC comprises three major jets coinciding with the Subantarctic Front (SAF), the PF, the Southern ACC Front, and Southern Boundary of the ACC (e.g., Orsi et al., 1995 (their Fig. 11); Sokolov and Rintoul, 2009 (their Fig. 6)). Across the Drake Passage, at about $66^{\circ} \mathrm{W}$, the ACC is divided into two branches as it rounds Burwood Bank (Fig. 1a) (Fetter and Matano, 2008). The eastern branch flows eastwards and around the MEB, where it joins the western northward-flowing branch at about $48^{\circ} \mathrm{S}$ to form the Falkland/Malvinas Current. A total of $\sim 100 \mathrm{SV}\left(1 \mathrm{SV}=10^{6}\right.$ $\mathrm{m}^{3} / \mathrm{s}$ ) of deep and bottom water from different origins crosses the F/MP and enters the Argentine Basin through three main north-south trending openings being the saddle of the F/MP (sill depth $2500 \mathrm{~m}$ ), the Falkland/ Malvinas Passage at $35-40^{\circ} \mathrm{W}$ (sill depth of $5100 \mathrm{~m}$ at the narrow Falkland/Malvinas Gap at $36^{\circ} \mathrm{W}$ ), and west of the Islas Orcadas Rise (sill depth $>4500 \mathrm{~m}$ ) (Fig. 1a). These water masses comprise Weddell Sea Deep Water (WSDW), South Pacific Deep Water (SPDW), Lower Circumpolar Deep Water (LCDW), and Upper Circumpolar Deep Water (UCDW) (Arhan et al., 1999; Arhan et al., 2002; Orsi et al., 1999) (Fig. 1a).

\section{Data and methods}

\subsection{Seismic reflection data acquisition and processing}

The presented study is based on a subset (ca. $2200 \mathrm{~km}$ ) of seismic reflection data acquired by the Alfred-Wegener-Institute (AWI) during RV Maria S. Merian cruise MSM81 in 2019 (Uenzelmann-Neben, 2019a) (Fig. 1b). A 240-channel digital seismic streamer (SERCEL SEAL@) with a hydrophone array spacing of $12.5 \mathrm{~m}$ (total active length $3 \mathrm{~km}$ ) in addition to a $141.4 \mathrm{~m}$-long lead-in cable was used to record $9 \mathrm{~s}$ of data sampled at $1 \mathrm{~ms}$. An array of 4 GI-guns with a total volume of ca. 9.61 constituted the seismic source. Each individual GI-gun consisted of a generator chamber ( 0.721 volume) producing the seismic signal and an injector chamber (1.68 1 volume) triggered with a $33 \mathrm{~ms}$ delay to minimize the bubble effect. The guns were fired every $25 \mathrm{~m}$, producing signals with frequencies of up to $300 \mathrm{~Hz}$.

Pre-processing of seismic data comprised navigation data merge, geometry definition, and CDP-sorting with a $25 \mathrm{~m}$ CDP spacing. For normal-move-out correction, a precise velocity analysis (at least) every $50 \mathrm{CDP}(\sim 1.2 \mathrm{~km})$ was carried out. Geometric spreading amplitude correction was applied before stacking. Furthermore, an Omega-X poststack time migration was included to attain a correct seismic image of the underground in the areas with high inclination (Yilmaz, 2001). Aiming for an amplitude preserved processing, no Automatic Gain Control filter (AGC) was applied neither throughout the processing sequence nor for display. A bandpass filter with a Hanning Window taper with low and high boundaries of $5-30 \mathrm{~Hz}$ and $200-250 \mathrm{~Hz}$, respectively, was applied for the display of the sections.

\subsection{DSDP drilling data}

Borehole information from four DSDP Leg 36 and Leg 71 sites are integrated into this study. The seismic profiles of cruise MSM81 were designed to intersect Leg 36 Sites 327, 329, and 330 and Leg 71 Site 511 (Uenzelmann-Neben, 2019a) (Fig. 1b). Fig. 2 provides an overview of the four DSDP sites in the study area.

\subsubsection{DSDP leg 36 site 327}

Including two boreholes, respectively 469.5 and $5.5 \mathrm{~m}$ deep, this site was drilled on the western shoulder of the MEB, at a water depth of 2400 m (Shipboard Scientific Party, 1974a). DSDP Site 327 was continuously cored up to $118 \mathrm{~m}$ and intermittently cored up to the bottom of the hole. In total $128.1 \mathrm{~m}$ core was recovered (50\% core recovery). Eight lithological units were distinguished, ranging in age from Neocomian-late Aptian to Quaternary (Figs. 2 and 3).

\subsubsection{DSDP leg 36 site 329}

DSDP Site 329 , located ca. $55 \mathrm{~km}$ northeast of DSDP Site 327 on the MEB, includes one borehole drilled on the westernmost end of the MEB 


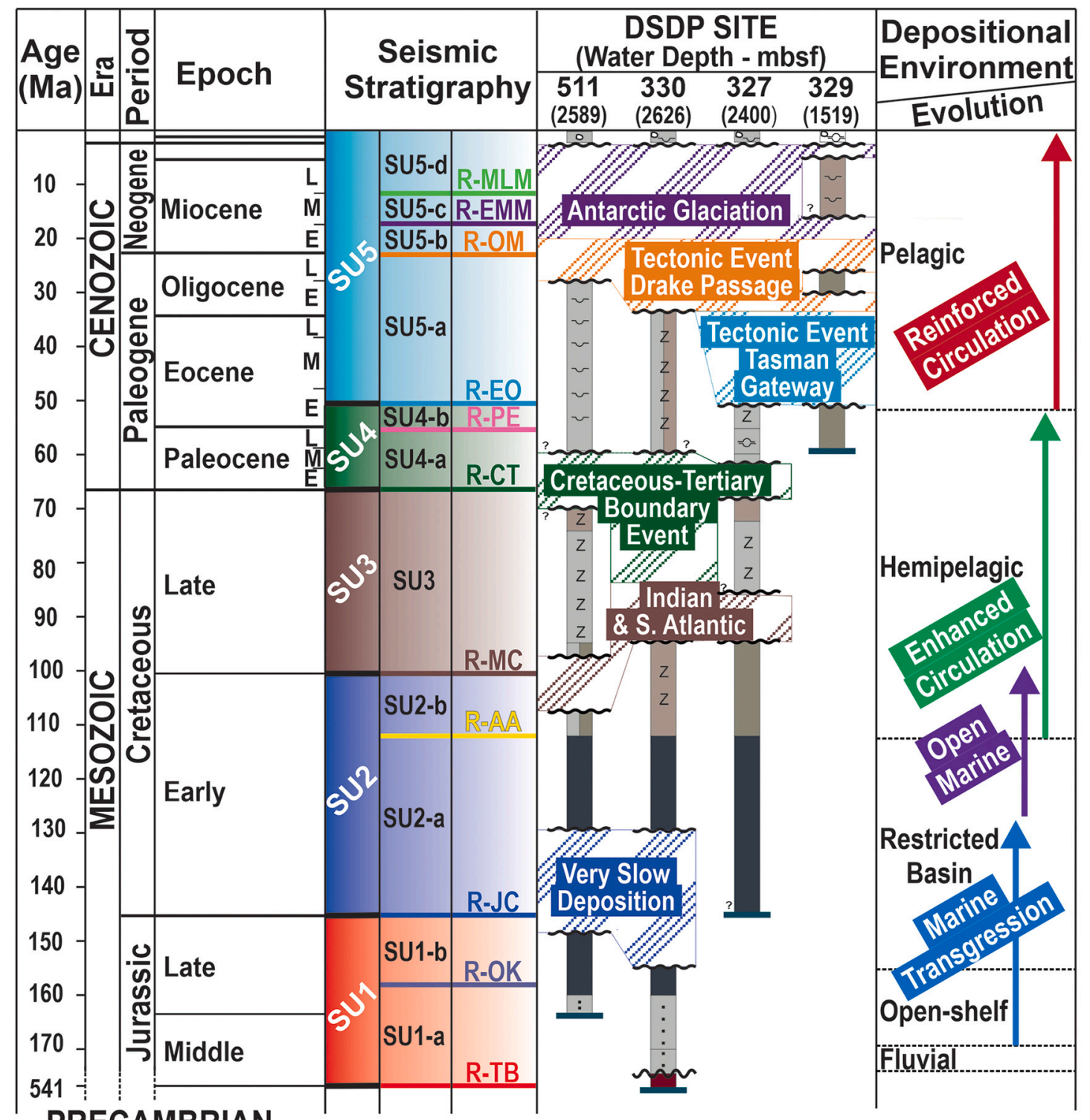

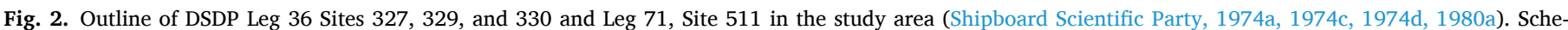

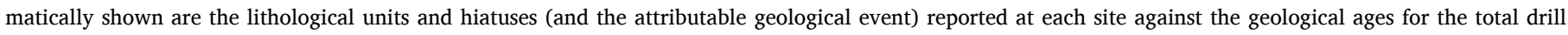

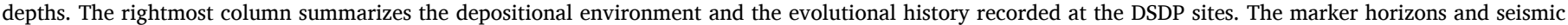
units defined in the seismostratigraphic model are also color marked (for more details, refer to Table 1 and Section 4).

to a depth of $464.5 \mathrm{~m}$, at a water depth of $1519 \mathrm{~m}$. DSDP Site 329 was continuously cored up to $179.5 \mathrm{~m}$ and intermittently cored up to the bottom of the hole (Shipboard Scientific Party, 1974c). The section comprised two lithological units ranging in age from Paleocene to Pleistocene-recent (Figs. 2 and 3).

\subsubsection{DSDP leg 36 site 330}

Including two boreholes, respectively 575.5 and $47.5 \mathrm{~m}$ deep, this site was drilled at the western end of the MEB, ca. $10 \mathrm{~km}$ southwest of DSDP Site 327, at a water depth of $2626 \mathrm{~m}$ (Shipboard Scientific Party, 1974d). DSDP Site 330 was intermittently cored up to a depth of 575.5 $\mathrm{m}$. In total $85.5 \mathrm{~m}$ core was recovered ( $53 \%$ core recovery). At a depth of $550 \mathrm{mbsf}$, the hole drilled into the gneissose and granitic continental basement. The section recorded seven lithological units ranging in age from Pre-Cambrian to Recent (Figs. 2 and 3).

\subsubsection{DSDP leg 71 site 511}

DSDP Site 511 was drilled and continuously cored $632 \mathrm{~m}$ within the basin province of the F/MP, ca. $10 \mathrm{~km}$ south of DSDP Site 330, at a water depth of 2589 m (Shipboard Scientific Party, 1980a). In total $385.62 \mathrm{~m}$ core was recovered (61\% core recovery). The section comprises six lithological units ranging in age from early Albian to early Oligocene (Figs. 2 and 3).

\subsection{Interpretation scheme}

\subsubsection{Integration of DSDP well data into seismic sections}

P-wave velocity models from measurements on the core material for the four DSDP sites in the study area were adopted to convert geological information from depth into two-way time domain since no downhole logging data was available. Velocity information for DSDP Sites 327, 329, and 330 were taken from Shipboard Scientific Party (1974a, 1974b, 1974c) and for DSDP Site 511 from Bayer (1980) (Fig. 3). DSDP Site 511 is the only site with a continuous coring interval; however, the recovery rate lies by only $61 \%$. Detailed information on shipboard sonic velocity measurement for Legs 36 and 71 inclusive of the methodology, 


\section{$\begin{array}{llll}\text { DSDP Site } 511 & \text { DSDP Site } 330 \quad \text { DSDP Site } 327 & \text { DSDP Site } 329\end{array}$}
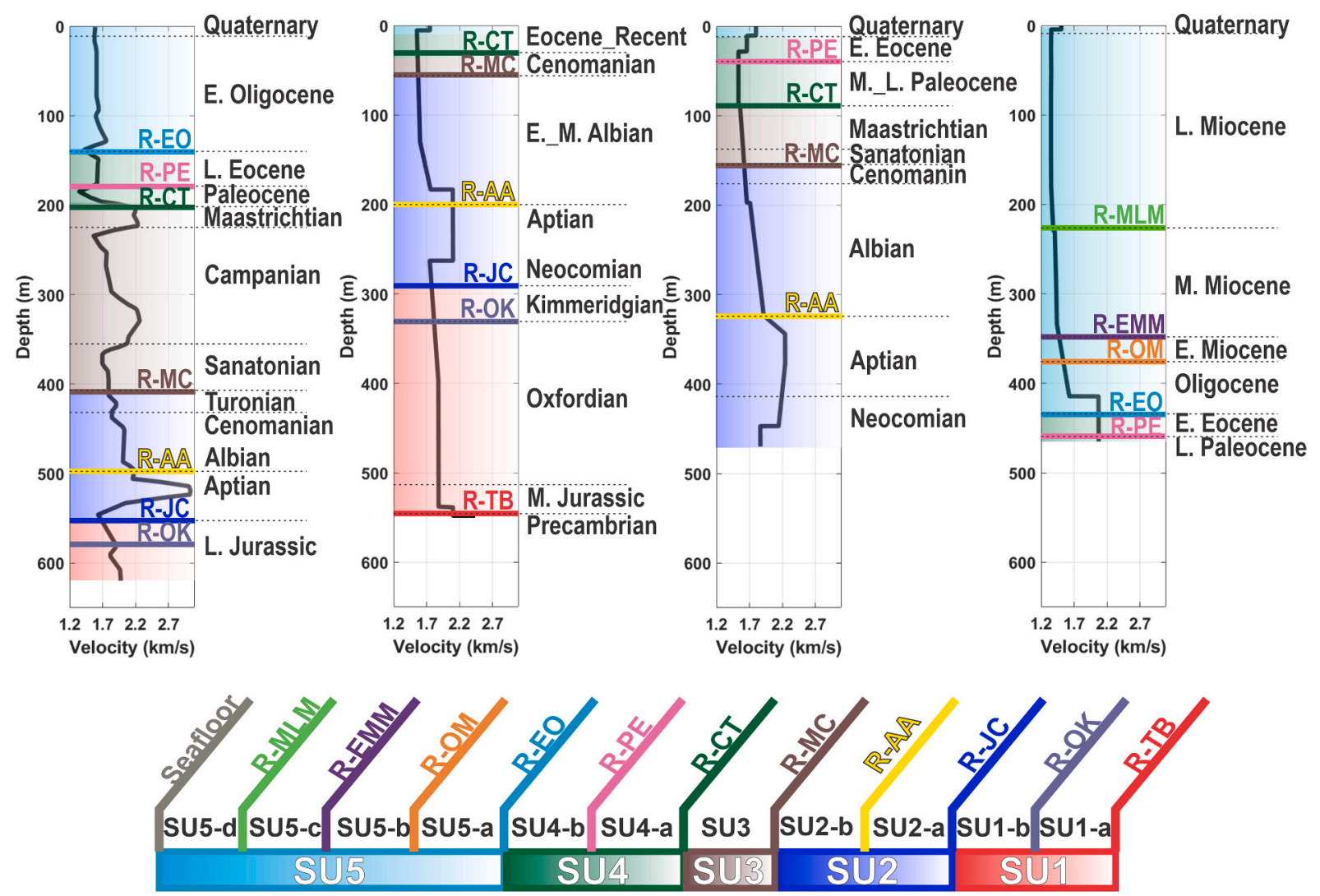

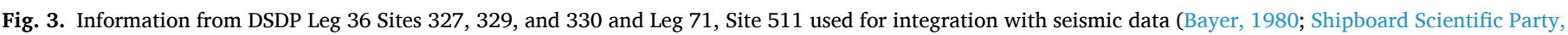

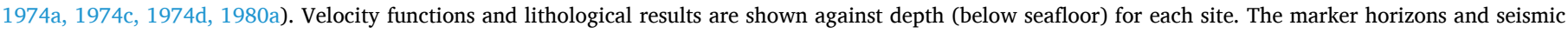
units defined in the seismostratigraphic model are also color marked (for more details, refer to Table 1 and Section 4).

limitations, potential sources of errors, and applied calibrations are explained by Lonardi (1974) and Bayer (1980). The velocity models from onboard measurements, integrated into this study, are assumed to be based on true values, with small errors. The depth-age conversion was applied for the DSDP boreholes using the velocity information. Reflectors were first traced in-between the sites and afterward extended outwards as far as the reflectors' continuities allowed. The observations of the depths and thicknesses, according to the seismic data are all in Two-Way Traveltime ms (TWT ms) or TWT ms below seafloor (TWT msbsf), hereafter only expressed as ms or msbsf. The expressed thicknesses in $\mathrm{ms}$ are converted to $\mathrm{m}$ using an average interval velocity for each (sub)unit.

\subsubsection{Seismic stratigraphy}

In principle, seismic stratigraphy is the technique of stratigraphic interpretation using seismic data within the limits of seismic resolution, where seismic images are divided into distinct stratigraphic packages through identification of prominent reflection terminations (Emery and Myers, 2009). Marking consistent reflector truncations against seismic surfaces allows for dividing the stratigraphy on seismic data into depositional packages with (semi-) conformable reflections with minor varying character. Categorization of reflection terminations is based on the geometric relationship between the reflections and the seismic surfaces against which they terminate. Reflection truncation terminology is here adopted from Mitchum Jr et al. (1977); Vail et al. (1977) and Emery and Myers (2009). The unconformities, distinguished by their high-relief truncational characteristic, are considered as sequence boundaries across which the units' strata show discordance (Emery and Myers, 2009; Vail et al., 1977).

\subsubsection{Seismic expression of contourites}

The observed sedimentary features (erosional patches/surfaces, moats, sediment mounds) are interpreted within the concept of currentcontrolled sedimentation, as practiced and adopted similarly within other study areas (e.g. Müller-Michaelis et al., 2013; Nielsen et al., 2008; Steinbrink et al., 2020; Uenzelmann-Neben et al., 2007). Bottom currents and water masses erode and transport sediments, depositing the material where the flow velocity is reduced. This concept of sediment drift formation has been defined and summarized by a number of authors (e.g., Esentia et al., 2018; Faugères and Stow, 2008; Faugères et al., 1999; Nielsen et al., 2008; Rebesco et al., 2014; Stow et al., 2002). A three-scale approach is proposed to best define the diagnostic criteria for the contourite drift systems, as shortly presented below.

Large-scale seismic criteria indicate a long-term stable oceanographic setting. These include:

- Typical geometries, mostly mounded, as an interactive product of the nature of the bottom current flow, topographic features, and sediment supply.

- Along-slope (down-current) elongation.

- Basal (ocean-wide) and internal (sub-regional) erosional discontinuities, marked by high-amplitude continuous reflectors, indicating changes in the bottom-current conditions.

- Uniform subunits with middle- to low-amplitude reflections in between the discontinuities, marking the temporal and spatial persistence of the bottom-current conditions.

Medium-scale seismic criteria are indicative of periodic deposition, non-deposition, and erosion marking the history of drift construction. 
These include:

- Mostly lenticular, upward-convex formed units.

- Progradational, aggradational, or uniform stacking pattern, in response to different drift systems, prone to change along the development of the drift.
- Down-current to oblique migration direction. Lateral migration is attributable to the action of Coriolis Force (increasingly at high latitudes).

- Reflector terminations in form of downlapping and sigmoidal progradational patterns.

Small-order seismic criteria reflect changes in the depositional facies, processes, and sediment types, these are however very dependent on the

Table 1

Seismostratigraphic model. Defined seismic stratigraphy and reflector nomenclature at DSDP Leg 36 Site 327, 329 , 330 , and Leg 71 Site 511.

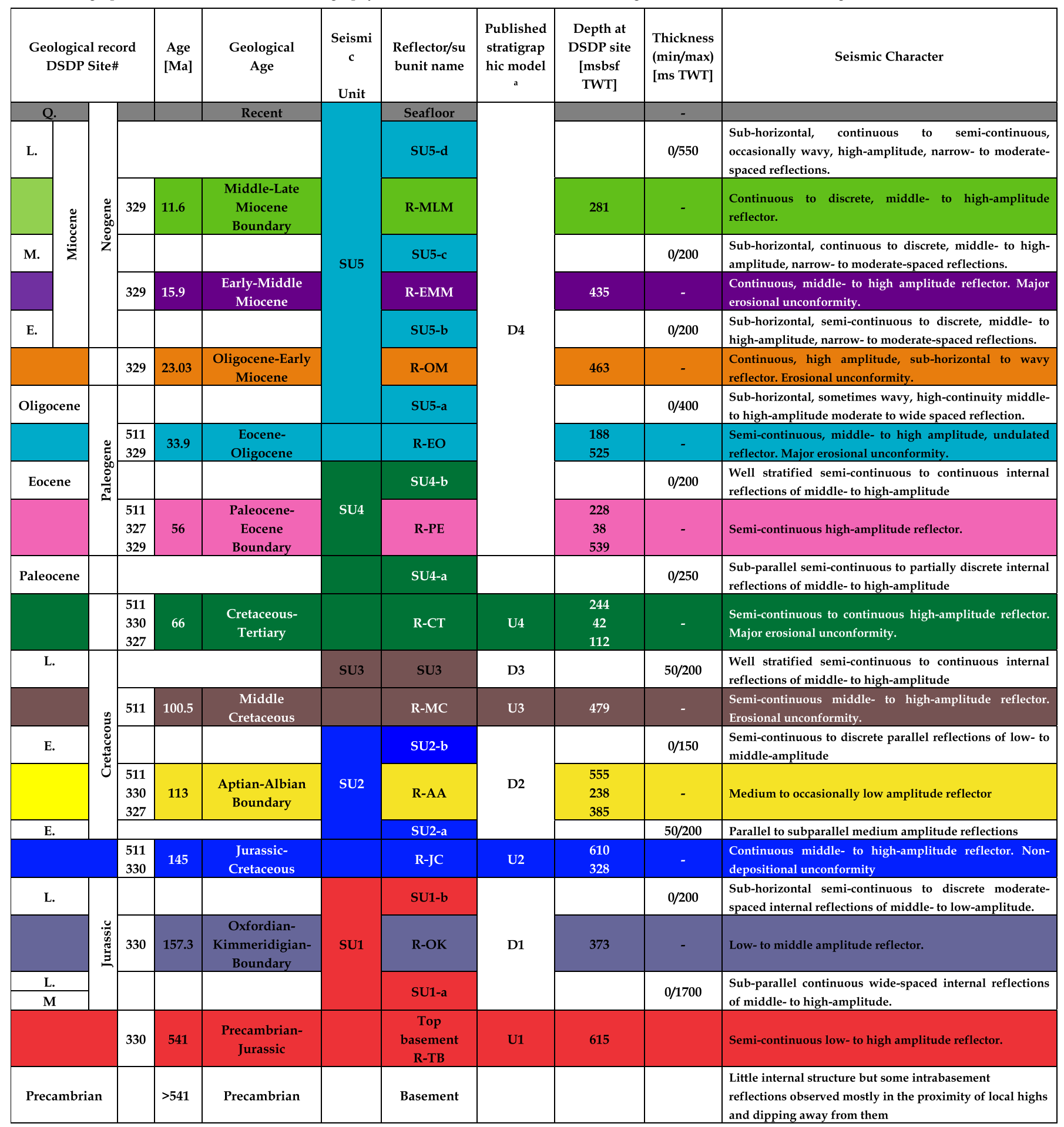

aLorenzo and Mutter, 1988. 
seismic acquisition and processing schemes and therefore should be integrated with other methods.

We thus interpret the observed sediment mounds as sediment drifts and together with moats and erosional patches/surfaces as the result of bottom current and bottom water mass activity.

\section{Results}

Five widespread seismic units were distinguished on the MEB, which are bound by unconformities sampled and biostratigraphically dated at the DSDP Sites 327, 329, 330, and 511 (Fig. 2.). The drilling data from the DSDP sites are correlated with observations of the reflection characteristics for both reflectors and seismic units. Several seismic horizons with distinct characters distinguish subunits of these sequences, as listed in Table 1.

\subsection{Basement}

The top of the basement, reflector R-TB, exhibits a twofold character. On the shoulder of the MEB, towards the Falkland/Malvinas Basin, it forms a low dip reflection of low-amplitude (Fig. 4, CDPs 800-1800). On top of the MEB, however, it exhibits a rough and indented topography, with semi-continuous, middle- to high-amplitude reflections (Fig. 5, CDPs 1-1500). Reflector R-TB occasionally reaches a maximum depth of more than 2500 msbsf towards the shoulder of the MEB (Fig. 4, CDPs 1200-1600) and shoals towards the top of the MEB, where it lies at an average depth of 600 msbsf (Fig. 5, CDPs 1-1600).

Basement highs are common across the MEB and exhibit different sizes. At their base, these show a width ranging from less than $5 \mathrm{~km}$ (Fig. 5, CDPs 1-200) to more than $22 \mathrm{~km}$ (Fig. 6, CDPs 600-1500). Some rise less than $200 \mathrm{~ms}$ relative to the adjacent basement (Fig. 5, CDPs 1600-1900), while others rise up to $1000 \mathrm{~ms}$. Locally, these highs can be traced close to the seafloor.

\subsection{Seismic units}

\subsubsection{Unit SU1, Reflectors R-TB to R-JC (Precambrian-Jurassic to} Jurassic-Cretaceous)

Unit SU1 is bound at the top by reflector R-JC, an approximately 25million-year non-depositional unconformity of late Jurassic-early Cretaceous age (Shipboard Scientific Party, 1974c, 1980a, 1980b), sampled at DSDP Sites 511 and 330 (Fig. 2, Table 1). Reflector R-JC is of continuous middle- to high-amplitude character and can be tracked well across the MEB (Fig. 7). Reflector R-TB forms the base reflector for unit SU1 (Fig. 7, Table 1).

Unit SU1 is split into the lower subunit SU1-a and the upper subunit SU1-b by reflector R-OK, which marks the Oxfordian-Kimmeridgian boundary at DSDP Site 330 (Shipboard Scientific Party, 1974c) (Fig. 2). Reflector R-OK appears as a low- to middle-amplitude reflector, sub-parallel to the basement topography, which onlaps onto basement in more elevated regions where the top basement rises to a depth of less than 3200 ms (Fig. 7, CDP $\approx 14,500$ ). Subunit SU1-a has subparallel continuous wide-spaced reflections of middle- to high-amplitude, while subunit SU1-b shows sub-horizontal semi-continuous to discrete moderate-spaced internal reflections of medium- to low-amplitude (Fig. 7).

Unit SU1 follows the topography of the basement and wedges out at the crest of the MEB, and its thickness is a function of the basement depth and varies between $50 \mathrm{~ms}(\approx 47 \mathrm{~m})$ and more than $1800 \mathrm{~ms}(\approx$ $1687 \mathrm{~m}$ ) in the vicinity of the MEB. Unlike subunit SU1-a, which shows a very variable thickness between 0 and $1700 \mathrm{~ms}(\approx 1658 \mathrm{~m})$, subunit SU1-b has an average thickness of $150 \mathrm{~ms}(\approx 139 \mathrm{~m})$ on the shoulder and top of the MEB (Figs. 4-9).

Unit SU1 is mainly characterized by a hemipelagic depositional system, that fills the topographic troughs within the basement and exhibits a retrogradational character on the MEB (Fig. 7). Towards the north, approaching the Falkland/Malvinas Escarpment, subunit SU1-a is heavily distorted (Fig. 6, CDPs 1500-2500, TWT > $3800 \mathrm{~ms}$ ).

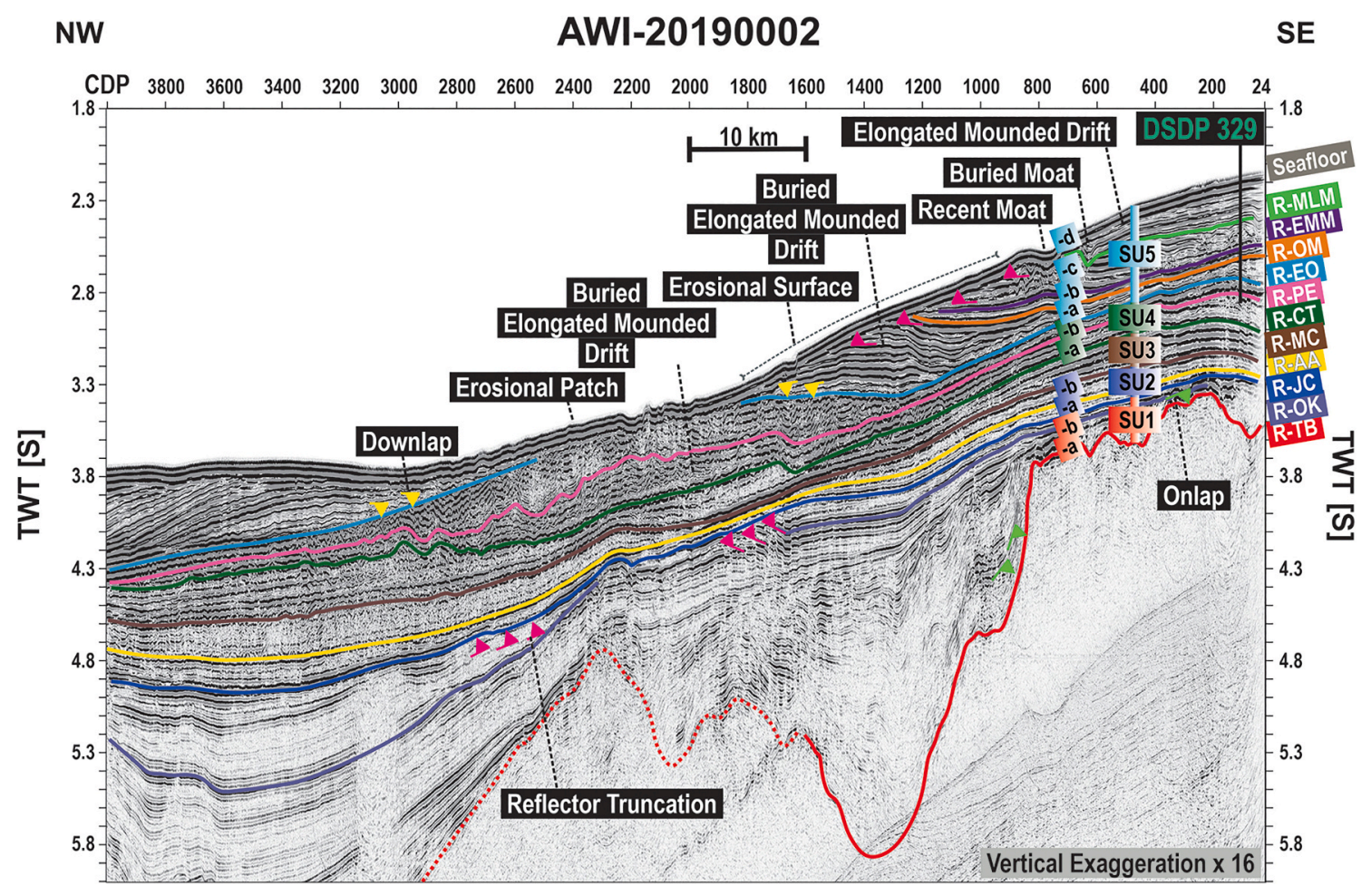

Fig. 4. Interpreted seismic profile AWI-20190002. Location of profile is shown in Fig. 1b. Superimposed are the defined seismic stratigraphy and the marker horizons (for more details, refer to Table 1 and Section 4). 
SSE

AWI-20190025

NNW

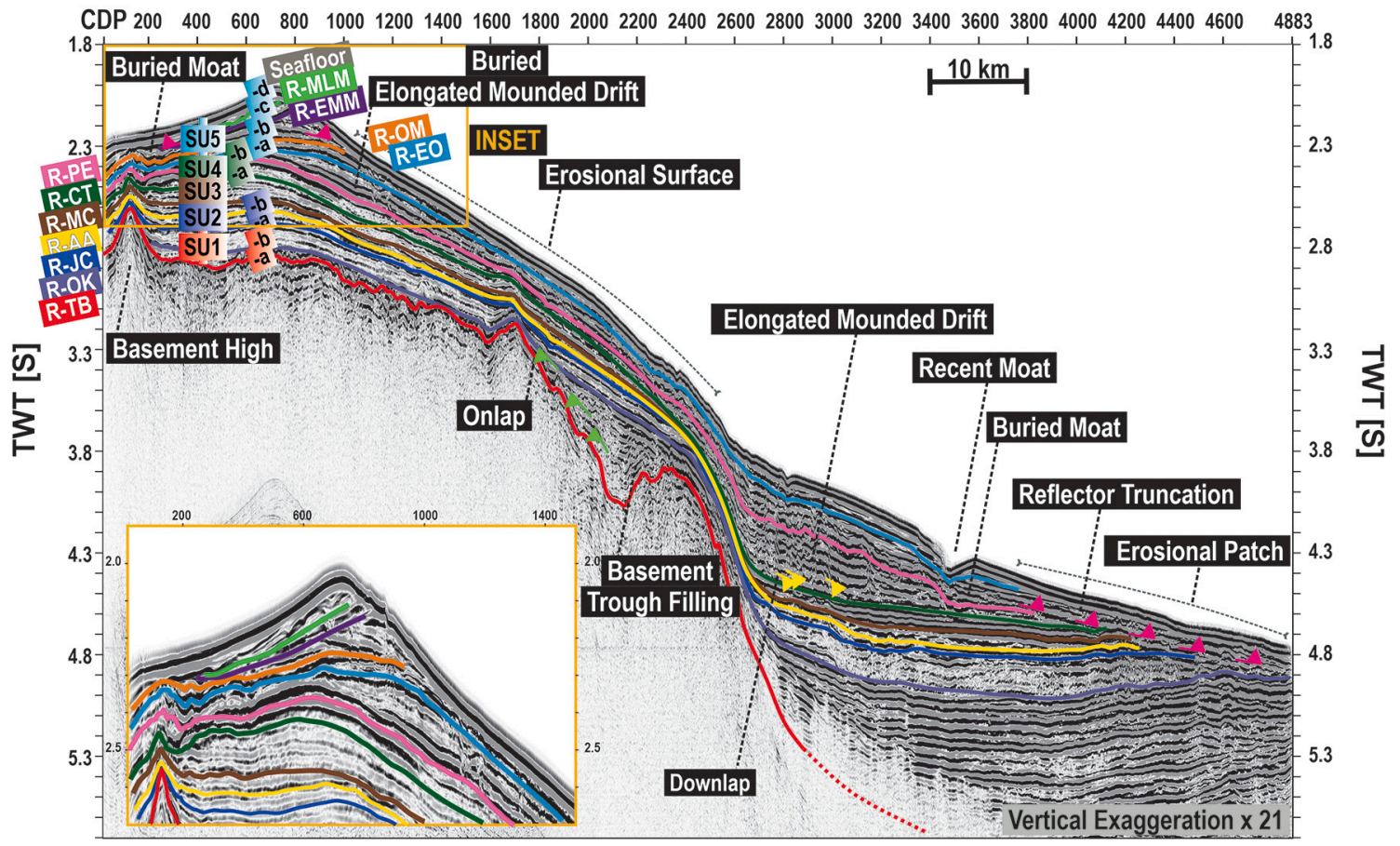

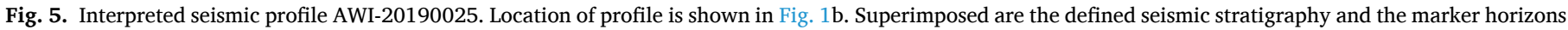
(for more details, refer to Table 1 and Section 4).

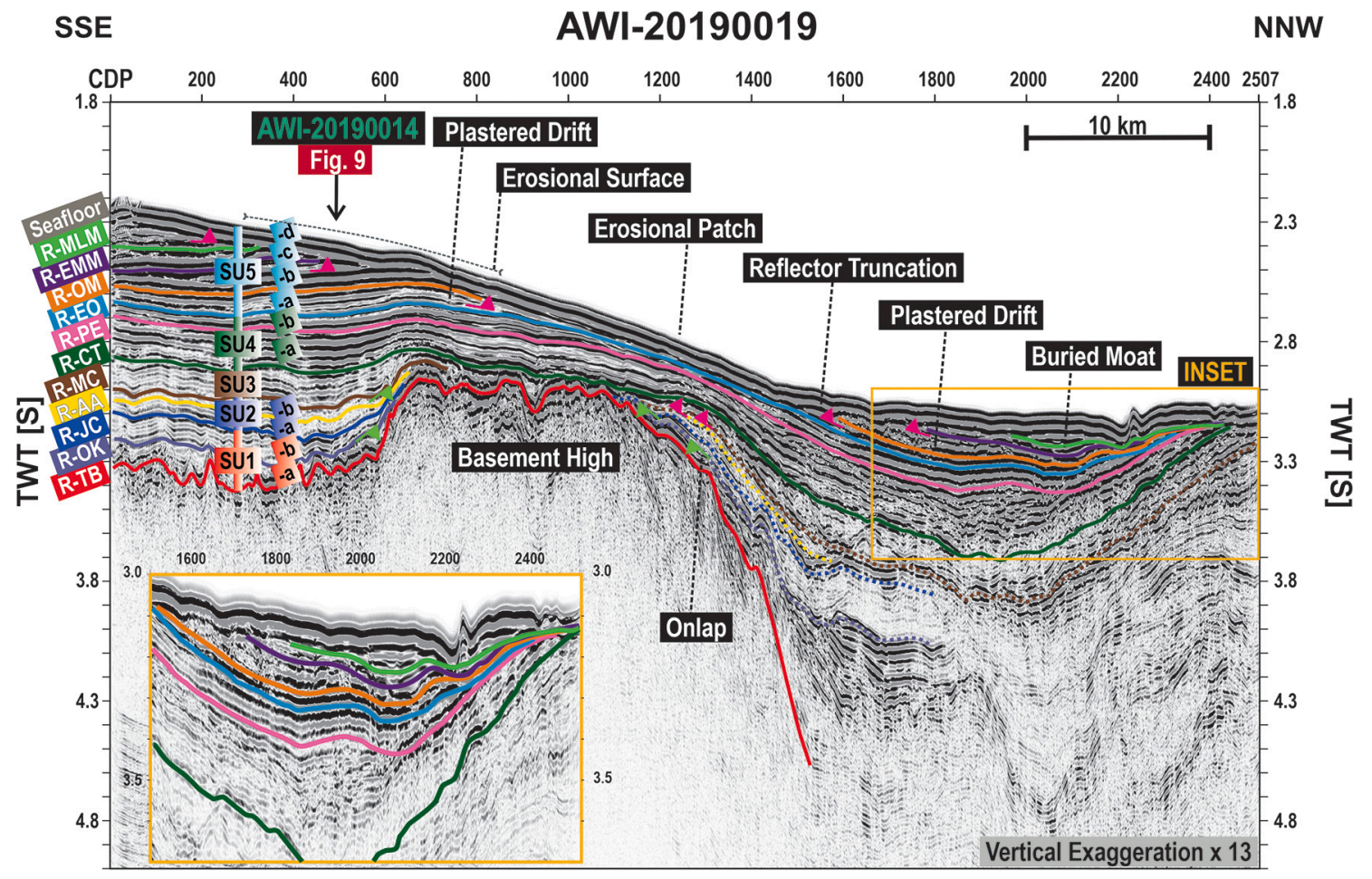

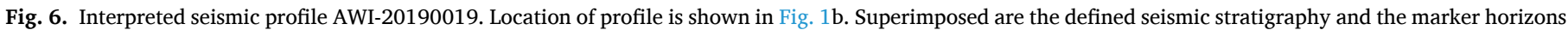
(for more details, refer to Table 1 and Section 4). Arrow shows the location of the crossing seismic profile.

\subsubsection{Unit SU2, Reflectors R-JC to R-MC (Jurassic-Cretaceous to Middle} Cretaceous)

Unit SU2 is bound at the base by reflector R-JC and at the top by reflector R-MC, which correlates to a middle Cretaceous hiatus as reported at DSDP Site 511 (Shipboard Scientific Party, 1980a) (Fig. 2, Table 1). Reflector R-MC appears as a semi-continuous middle- to highamplitude reflector across the MEB, which erosionally truncates reflections as old as the Albian (Fig. 4, CDPs 1600-2000, 700 msbsf). 
sw

AWI-20190001

NE

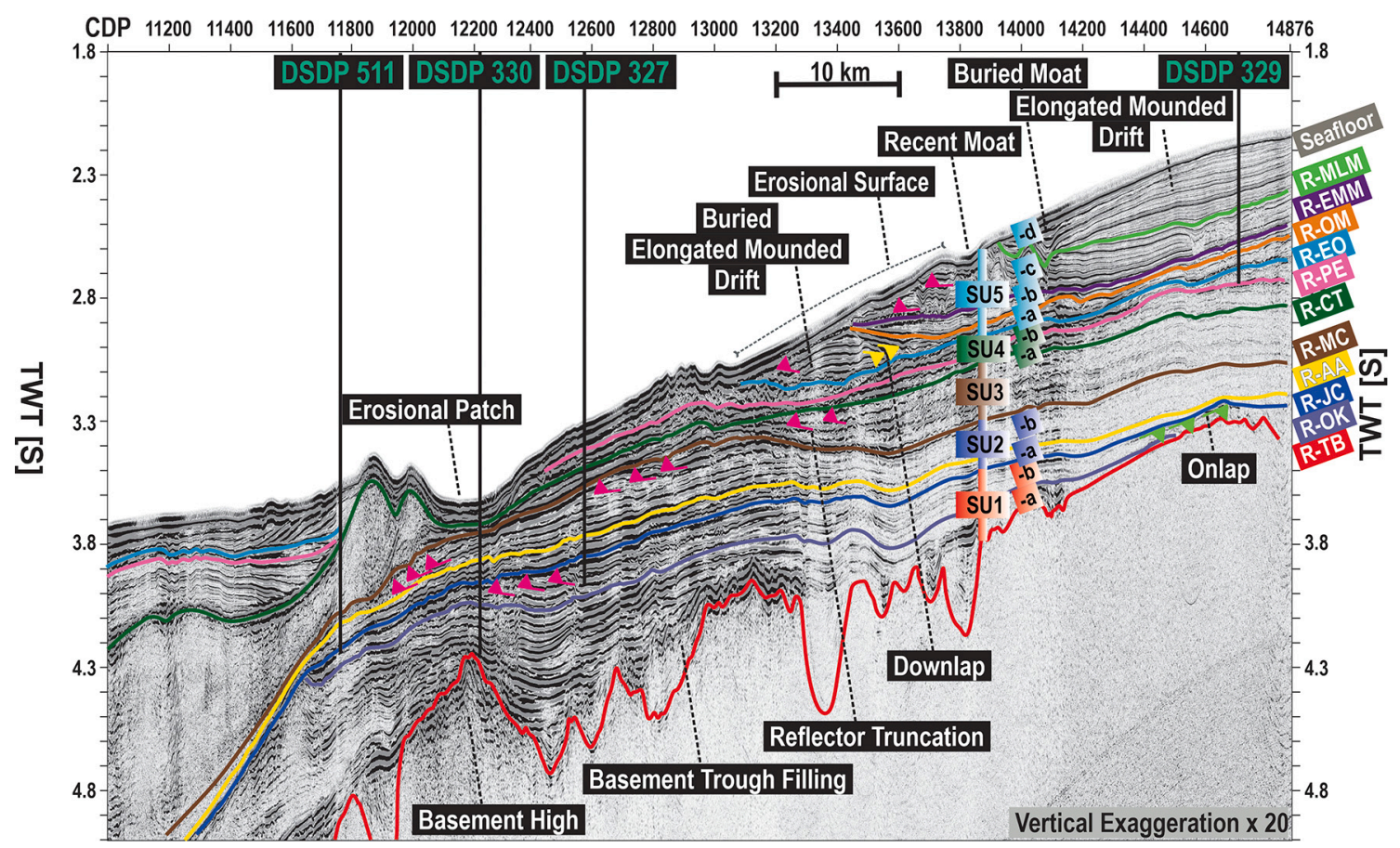

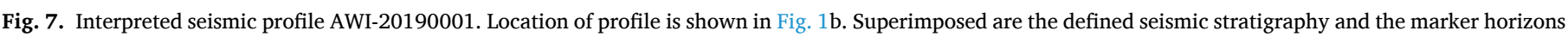

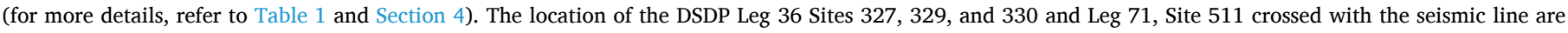
marked with thick black lines.

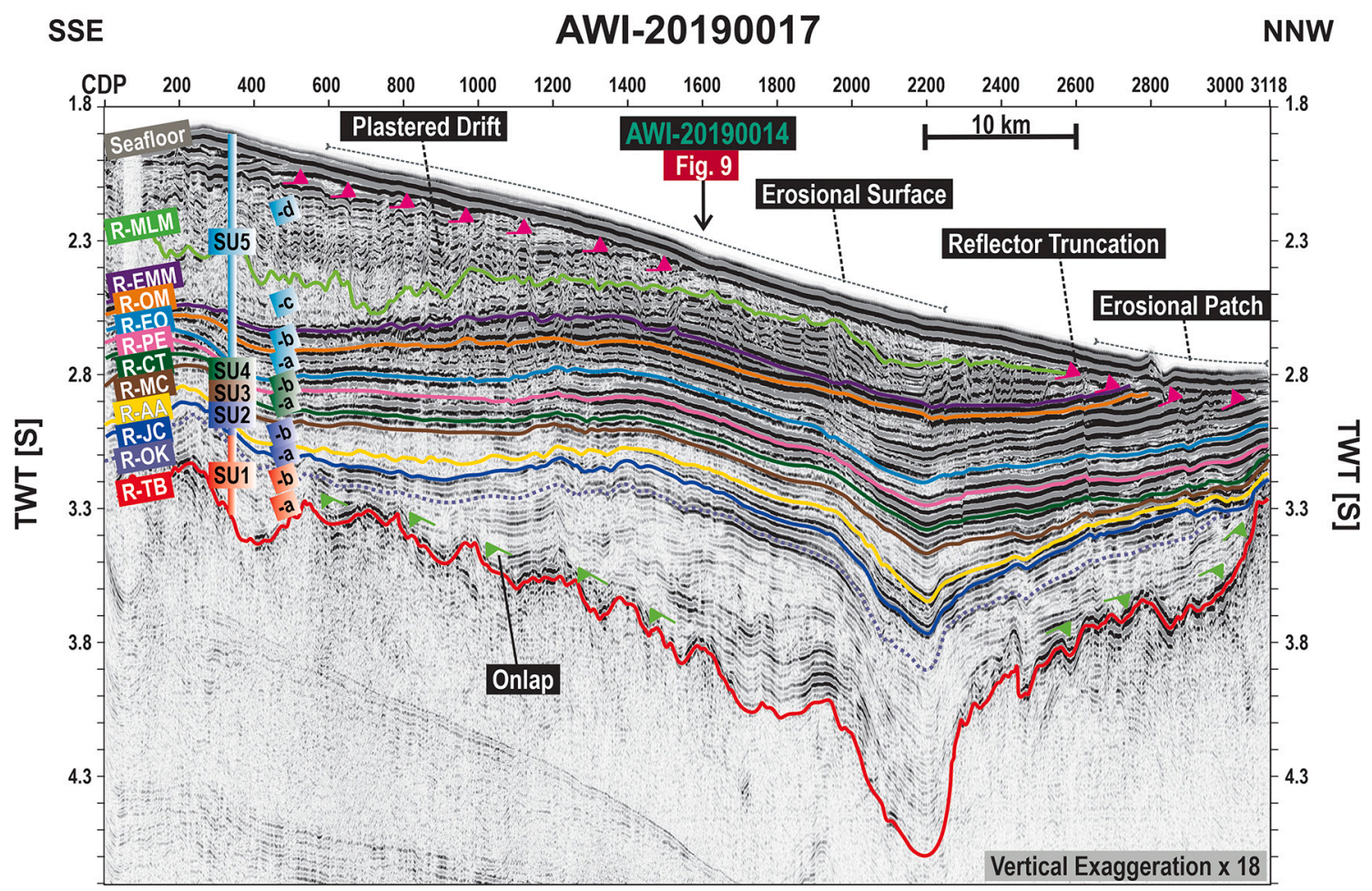

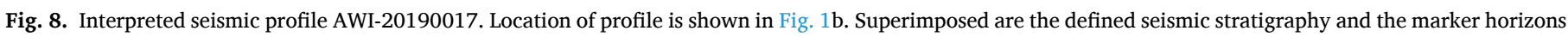
(for more details, refer to Table 1 and Section 4). Arrow shows the location of the crossing seismic profile.

Reflector R-AA of semi-continuous low- to middle-amplitude, which marks the Aptian-Albian boundary (Shipboard Scientific Party, 1974a, 1974c, 1980a, 1980b), separates unit SU2 into subunits SU2-a and SU2- b. Subunit SU2-a exhibits subparallel middle-amplitude reflections, while subunit SU2-b has subparallel semi-continuous to discrete reflections of low- to middle-amplitude (Fig. 7 and Fig. 8). Unit SU2 shows 


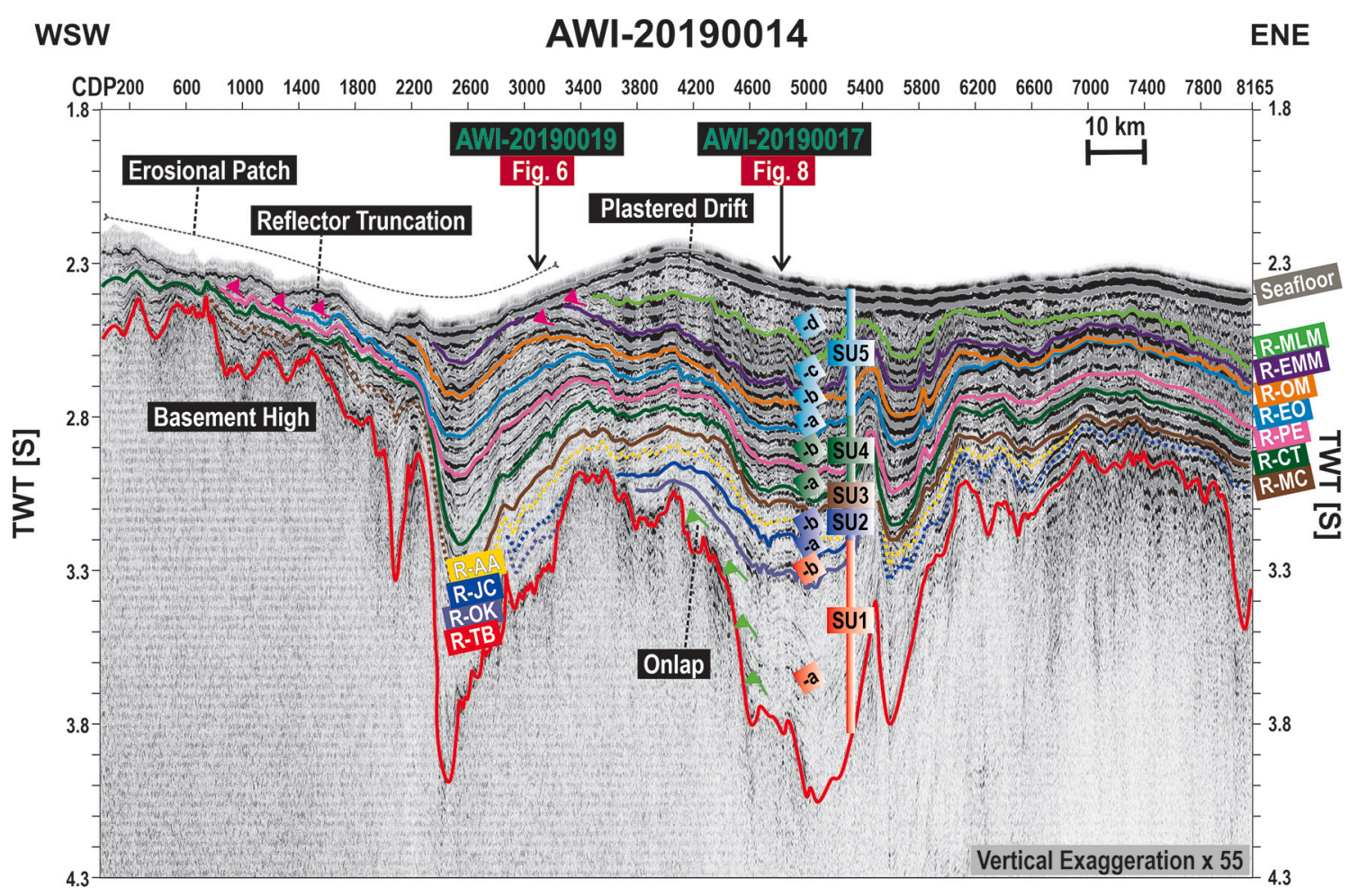

Fig. 9. Interpreted seismic profile AWI-20190014. Location of profile is shown in Fig. 1b. Superimposed are the defined seismic stratigraphy and the marker horizons (for more details, refer to Table 1 and Section 4). Arrows show the location of the crossing seismic profile.

a thickness between $50 \mathrm{~ms}(52 \mathrm{~m})$ and more than $350 \mathrm{~ms}(364 \mathrm{~m})$ in the vicinity of the MEB, with subunit SU2-a showing a constant thickness of ca. $100 \mathrm{~ms}(118 \mathrm{~m})$ and subunit SU2-b showing a more variable thickness, ranging from less than 50 to $200 \mathrm{~ms}$ (45-180 m) (Fig. 7 and Fig. 8). Towards the MEB's crest unit SU2 thins and occasionally disappears (Fig. 7), it thickens again towards greater water depths. This unit wedges out on the crest of the MEB once the top basement rises to less than ca. 2300 ms (Fig. 9).

Unit SU2 is strongly affected by erosion in depths of $3200-3800 \mathrm{~ms}$ $(2400-2850 \mathrm{~m})$ at the western flank of the MEB (Fig. 6, CDPs $1500-2000)$ and in depths of $4100-4700 \mathrm{~ms}(3075-3525 \mathrm{~m})$ in the depression north of the MEB.

\subsubsection{Unit SU3, Reflectors R-MC to R-CT (Middle Cretaceous to Cretaceous-Tertiary)}

Seismic unit SU3 is bound by reflector R-MC at its base and a major regional erosional unconformity, reflector R-CT, identified at DSDP Sites 511, 330, and 327 (Shipboard Scientific Party, 1974a, 1974c, 1980a, 1980b) (Fig. 2, Table 1), at its top. Reflector R-CT mostly has a semicontinuous to continuous high-amplitude character, can be traced very well across the MEB and truncates reflections as old as unit SU2 (Fig. 7, CDPs 12,100-13,500 and Fig. 6, CDPs 600-1600).

Unit SU3 shows sub-parallel semi-continuous to continuous internal reflections of middle- to high-amplitude. Lower reflections of unit SU3 lie conformably on reflector R-MC, while reflections within the upper part are erosionally truncated by the top reflector R-CT (Fig. 6, CDPs 12,100-14,800). Unit SU3 shows slightly variable thickness of ca. 200 $\mathrm{ms}(\approx 173 \mathrm{~m})$ across the MEB, but drops to less than $50 \mathrm{~ms}(\approx 44 \mathrm{~m})$ on the western flank (Fig. 7, CDPs 12,000-12,800). The unit thickens again westward into the Falkland/Malvinas Basin.

Onlap and erosional truncation characterize unit SU3 in the west in depths of 3200-3800 ms (2400-2850 m) where it thins strongly and appears to be affected by erosion (Fig. 7, CDPs 12,000-13,000 and Fig. 4, CDPs 1100-1600). There, unit SU3 forms the youngest present unit (Fig. 7, CDPs 12,100-12,300, location of DSDP Site 330). The unit is further strongly affected by erosion in depths of $4100-4700 \mathrm{~ms}$ $(3075-3535 \mathrm{~m})$ at the northern flank of the MEB (Fig. 5, CDPs 4300-4800) and in the depression in the north. In the northwestern corner of the depression, a filled moat is identified, which shows an updip westward migration (Fig. 5, CDPs 3200-4700).

\subsubsection{Unit SU4, Reflectors R-CT to R-EO (Cretaceous-Tertiary to Eocene- Oligocene)}

Unit SU4 is bound at the top by reflector R-EO, a prominent undulated, semi-continuous, middle- to high-amplitude reflector (Fig. 7), which marks an early to middle Eocene hiatus recorded at the DSDP Site 329 (Shipboard Scientific Party, 1974b) (Fig. 2, Table 1). Unit SU4 unconformably lies on the base reflector R-CT.

Reflector R-PE is a semi-continuous high-amplitude reflector marking the Paleocene-Eocene Boundary (Shipboard Scientific Party, 1974a, 1974b) and separates unit SU4 into subunits SU4-a and -b. Reflector R-PE mostly is sub-parallel to reflector R-CT and displays a semi-continuous high-amplitude reflection across the MEB (Fig. 7). Subunit SU4-a shows sub-parallel semi-continuous to partially discrete internal reflections of middle- to high-amplitude, and subunit SU4-b has more continuous internal reflections (Fig. 5). The internal reflections of subunit SU4-a are subparallel to reflector R-CT, while the reflections of subunit SU4-b are erosionally truncated by reflector R-EO at the top (Figs. 4-9).

Unit SU4 shows limited thicknesses on top of the MEB with an average of ca. $200 \mathrm{~ms}(\approx 165 \mathrm{~m}$ ) (Figs. 4-9). This unit shows thinning towards the flanks of the MEB and can therefore be mostly distinguished on the deeper shoulder or within the northern depression, where it thickens again and shows an average thickness of $400 \mathrm{~ms}(\approx 330 \mathrm{~m})$ (Figs. 4 and 5).

On the western flank of the MEB, subunit SU4-a locally shows a mounded structure with an average thickness of $200 \mathrm{~ms}(\approx 155 \mathrm{~m})$ developed to the west of an erosional patch lain against the western flank of the MEB at a depth range of 3200-3800 ms (2400-2850 m) (Fig. 4, CDPs 1200-3000). The mounded body shows sub-parallel 
internal reflections, extends northwards, and further develops into subunit SU4-b to an average thickness of $250 \mathrm{~ms}(\approx 219 \mathrm{~m})$ (Fig. 10, SU4-a and -b). Within this sediment body, the internal reflections of subunit SU4-a onlap reflector R-CT, while internal reflections of subunit
SU4-b are terminated by reflector R-EO (Fig. 4).

A mounded sediment body, with an average thickness of $100 \mathrm{~ms}(\approx$ $78 \mathrm{~m}$ ), develops within subunit SU4-a on top of the MEB, which extends towards the east (Fig. 5, CDPs 1-2000 and Fig. 10, SU4-a). This structure
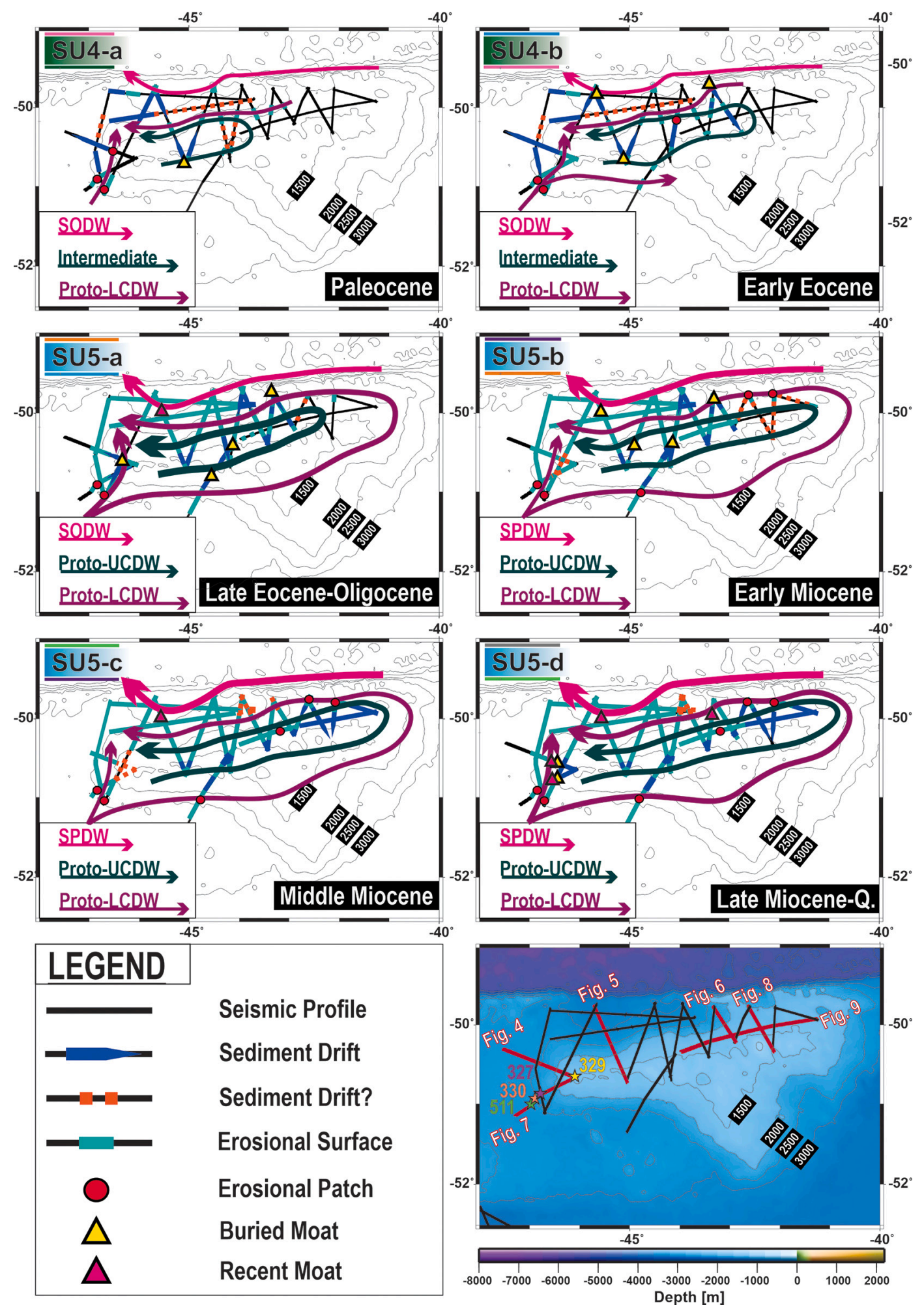

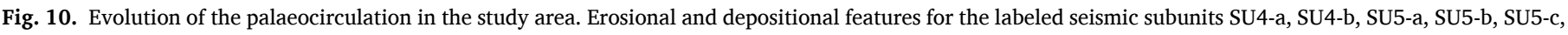

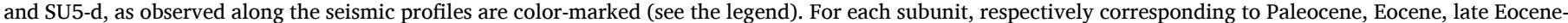

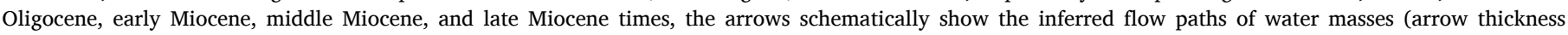

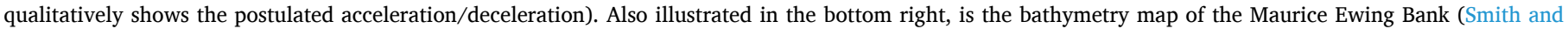
Sandwell, 1997), superimposed by the location of the seismic profiles and DSDP Leg 36 Sites 327, 329, and 330 and Leg 71, Site 511. 
further persists within subunit SU4-b with the crest migrating northwards, showing an average thickness of $150 \mathrm{~ms}(\approx 132 \mathrm{~m})$, (Fig. 5, CDPs 1-2000 and Fig. 10, SU4-b). A filled moat limits this asymmetric sediment mound at a depth range of $2400-2500 \mathrm{~ms}(1800-1850 \mathrm{~m})$ and displays a gradual updip northward migration, where the internal reflections of this mounded body downlap onto reflector R-CT (Fig. 5, CDP $\approx 200,400$ msbsf).

The two subunits of SU4 show strong thinning at the northern flank of the MEB within a depth interval of 3200-3800 msbsf (2400-2850 m) (Fig. 5, CDPs 2000-2500). Occasionally, subunit SU4-b thins abruptly and partly disappears leaving subunit SU4-a exposed at the seafloor. On the northern flank of the MEB, erosion further affects subunits SU4-a and SU4-b at depths between 2500 and $3000 \mathrm{~ms}$ (1875-2250 m) (Fig. 6, CDPs 1000-1500 and Fig. 10, SU4-a and -b). There, an asymmetrical mounded structure builds up within subunit SU4-b, showing an average thickness of $75 \mathrm{~ms}(\approx 66 \mathrm{~m})$ and a westward elongation, with a moat carved at a depth of ca. $3300 \mathrm{~ms}$ (2475 m) to its north (Fig. 10, SU4-b). This sediment body further persists within unit SU5 (Fig. 10, SU5-a to -d), where it builds up to an average thickness of $400 \mathrm{~ms}(\approx 298 \mathrm{~m})$.

Extreme erosion is observed at a depth interval of ca. $4100-4700 \mathrm{~ms}$ (3075-3525 m) within the southernmost section of the northern depression (Fig. 5, CDPs 2600-4800). There, subunit SU4-a outcrops in the central and western sections. However, younger sediments are present on top of subunit SU4-a on the shallower eastern section. Subunit SU4-a locally shows prominent downlaps onto base reflector R-CT in the northern depression, where the subunit shows an average thickness of $200 \mathrm{~ms}(\approx 155 \mathrm{~m}$ ) (Fig. 5, CDPs 2800-4400). This sediment buildup persists in subunit SU4-b, showing a westward extension (Fig. 10, SU4-a and -b). A moat is identified north of this sedimentary structure at a depth interval of 4600-4700 ms (3450-3525 m) with its steeper flank towards the northern flank of the MEB and a gradual southward updip migration (Fig. 5, CDPs 3400-3700 and Fig. 10, SU4-a and -b). Here, a recent moat is carved into the seafloor and sediments of unit SU5 in depths of ca. $4400 \mathrm{~ms}$ (3300 m) (Fig. 5, CDP $\approx 3500$ and Fig. 10, SU4-b).

\subsubsection{Unit SU5, Reflectors R-EO to Seafloor (Eocene-Oligocene to Recent)}

Unit SU5 lies unconformably on base reflector R-EO and is bound at the top by the seafloor (Figs. 4-9). This unit is separated into four subunits SU5-a, -b, -c, and - $d$ by reflectors R-OM, R-EMM, and R-MLM.

Subunit SU5-a is bound by base reflector R-EO and top reflector ROM. Reflector R-OM forms a sub-horizontal to wavy, continuous, highamplitude reflector (Fig. 7) and at DSDP Site 329 is referred to as an Oligocene to early Miocene hiatus (Shipboard Scientific Party, 1974b) (Fig. 2, Table 1). Reflector R-OM can be tracked well over most of the $\mathrm{MEB}$, truncating reflections of subunit SU5-a and occasionally onlapping reflector R-EO, the top reflector of subunit SU4-b (Fig. 6). The internal structure of subunit SU5-a is composed of sub-horizontal to wavy, highcontinuity moderate to wide-spaced middle- to high-amplitude reflections (Figs. 4-9).

Subunit SU5-b is bound by the base reflector R-OM and the top reflector R-EMM. Reflector R-EMM is a continuous high-amplitude reflector across the top of the MEB, that marks an early to middle Miocene hiatus at DSDP Site 329 (Shipboard Scientific Party, 1974b) (Fig. 2, Table 1). Subunit SU5-b shows sub-horizontal, semi-continuous to discrete, narrow- to moderately-spaced, middle- to high-amplitude reflections (Figs. 4-9).

Subunit SU5-c is bound by the base reflector R-EMM and the top reflector R-MLM. Reflector R-MLM displays a continuous to discrete high amplitude reflection on the MEB (Figs. 4-9), which marks the boundary between middle and late Miocene (Shipboard Scientific Party, 1974b) (Fig. 2, Table 1). Subunit SU5-c shows sub-horizontal, continuous to discrete, narrow- to moderately-spaced, middle- to highamplitude reflections and includes moats and wavy reflections (Figs. 4 and 7). Internal reflections of subunit SU5-c show abrupt changes of reflection amplitude and are mostly moderately-spaced (Fig. 7).

Subunit SU5-d is bound by reflector R-MLM at the base and the seafloor at the top and shows sub-horizontal, locally wavy, continuous to semi-continuous, narrow- to moderate-spaced, high-amplitude reflections (Figs. 7 and 8). Within the internal reflections of SU5-d, abrupt changes of the amplitude can be observed.

Unit SU5 forms asymmetric mounded sediment packages and can mostly be traced on the elevated part of the MEB. From $500 \mathrm{~ms}(\approx 373$ m) thickness on the western flank (Fig. 4, CDPs 200-1800), the unit thins towards the crest of the MEB to about $300 \mathrm{~ms}(\approx 224 \mathrm{~m})$ (Fig. 5, CDPs 1-1000) and thickens again on the eastern flank, where it reaches its maximum thickness of $1000 \mathrm{~ms}(\approx 745 \mathrm{~m}$ ) (Fig. 8, CDPs 1-1000).

In the west, a prominent erosional surface limits the occurrence of unit SU5 in depths of 3000-3800 ms (2250-2850 m) (Fig. 7, CDPs 12,200-13,100 and Fig. 10, SU5-a to -d). The one seismic profile at the southern flank of the MEB also highlights thinning and erosion of unit SU5 in depths of 3300-3700 ms (2475-2775 m) (Fig. 10, SU5-a to -d). Towards the east, strong erosion has taken place in depths of 2700-3000 ms (2025-2250 m) (Fig. 8, CDPs 2600-3100 and Fig. 6, CDPs 800-1600). At the northern flank of the MEB, the unit also shows strong thinning and is severely affected by erosion in depths of 2400-3900 ms (1800-2925 m) (Fig. 5, CDPs 1000-2600 and Fig. 10, SU5-a- to d). Here, the MEB is locally devoid of sediments younger than unit SU5-a at an average depth of 2200-2400 ms (1650-1750 m) (Fig. 9, CDPs 1-1400).

An asymmetrical mounded sediment body onlapping reflector R-EO is observed on the western flank of the MEB within subunit SU5-a (Fig. 7, CDPs 13,100-13,600, Fig. 4, CDPs 1000-1800). The deposit forms an elongated sediment body, lying against the western flank of the MEB, in a depth range of ca. $2900-3300 \mathrm{~ms}$ (2175-2475 m). It measures ca. 15 $\mathrm{km}$ in width with a maximum thickness of ca. $200 \mathrm{~ms}(\approx 160 \mathrm{~m})$ at about $50.8^{\circ} \mathrm{S}$, shows larger width and thickness towards the north (ca. $25 \mathrm{~km}$ wide and ca. $400 \mathrm{~ms}$ at about $50.5^{\circ} \mathrm{S}$ ) and is accompanied by a filled moat to its east (Fig. 4, CDPs $\approx 1100$ and Fig. 10, SU5-a). The moat has its steeper flank against the western flank of the MEB. The apex of the concave sediment body as well as the filled moat show an updip migration.

On top of the MEB, an asymmetrical slightly mounded sediment pile flanked by a moat in the south is located within subunit SU5-a in a depth range of $2200-2400 \mathrm{~ms}$ (1650-1800 m) (Fig. 5, CDPs 1-2000 and Fig. 10, SU5-a). On the northern flank of the MEB, the continued presence of a slightly mounded sediment pile, already identified in subunit SU4-b, can be observed within similar water depths (Fig. 6, CDPs 1-800 and Fig. 10, SU5-a). At its base, this sediment pile measures an average of $10 \mathrm{~km}$ and shows a maximum thickness of $200 \mathrm{~ms}(\approx 150 \mathrm{~m})$ (Fig. 6). The apex of the mounded sediment body, as well as the concavity of the adjacent moat, show an updip southward migration. On the southern flank of the MEB, a sediment body is present within subunit SU5-a, showing channels within its structure and extensive erosion at the top.

The asymmetric mounded sediment body observed in subunit SU5-a on top of the MEB further persists into subunit SU5-b. The deposit is strongly affected by erosion, within a depth of 2400-3900 ms (1800-2925 m) (Fig. 5, CDPs 1-1100 and Fig. 10, SU5-b). The sediment mound attached to the northern MEB flank in the northern depression, which was already observed in subunits SU4-b and SU5-a, persists in subunit SU5-b (Fig. 6, CDPs 1600-2200 and Fig. 10, SU5-b). A semisymmetrical sediment body unconformably occurs in subunit SU5-b on the southwestern flank of the MEB in depths of $2300-2900 \mathrm{~ms}$ $(1725-2175 \mathrm{~m})$. At its base, it is about $35 \mathrm{~km}$ wide and builds up to an average thickness of $100 \mathrm{~ms}(\approx 75 \mathrm{~m})$.

On the western flank and top of the MEB, subunit SU5-c shows a wavy character with an average length and height of ca. of $200 \mathrm{~m}$ and $30 \mathrm{~ms}$ (Fig. 7, CDPs 13,600-14,000). Similar to subunit SU5-b, subunit SU5-c also shows extensive erosion at the crest of the MEB within depths of. 2200-2400 ms (1650-1750 m) (Fig. 5, CDPs 1-1000 and Fig. 9, CDPs 1-2400). This subunit is also eroded to a great extent at the northern flank of the MEB within a depth of 2200-3900 ms (1650-2925 m). Deeper on the southern flank of the MEB, the attached sediment mound, 
which was initially observed in subunit SU5-b, persists in subunit SU5-c (Fig. 10, SU5-c). The symmetric mounded sediment body, first identified within subunit SU4-b in the northern depression, prevailed into subunits SU5-a and -b, is further maintained with an average thickness of $75 \mathrm{~ms}$ $(\approx 55 \mathrm{~m})$ in subunit SU5-c (Fig. 10, SU5-c).

Subunit SU5-d is the youngest and by far the thickest subunit of unit SU5 (Figs. 7 and 8). On the western part, subunit SU5-d shows a mounded sediment body with an average thickness of ca. $200 \mathrm{~ms}(\approx 140$ $\mathrm{m}$ ) and includes a filled moat, with an average width and height of 850 $\mathrm{m}$ and $100 \mathrm{~ms}$, showing an eastward updip migration (Fig. 7, CDPs 13,800-14,800). Here, a recent moat is carved into the seafloor (Fig. 7, $\mathrm{CDP} \approx 13,820$, Fig. 6, CDP $\approx 770$, and Fig. 10, SU5-d). Towards the crest of the MEB, subunit SU5-d thins to less than $50 \mathrm{~ms}$ (Fig. 5, CDPs 800-400). Similar to other subunits of unit SU5, subunit SU5-d also shows extensive erosion/non-deposition on the southern flank of the MEB, where reflector R-MLM onlaps reflector R-EMM at depths of 2100-2200 ms. This deposit is strongly eroded at the northern flank of the MEB within a depth of 2100-3900 ms (1575-2925 m).

Towards the east, however, subunit SU5-d thickens enormously and displays an average thickness of $200 \mathrm{~ms}(\approx 140 \mathrm{~m})$ at the northern flank and an average thickness of $500 \mathrm{~ms}(\approx 350 \mathrm{~m})$ towards the crest (Fig. 8). Here, extensive erosion has taken place at an average depth of 2600-2700 ms (1950-2025 m) (Fig. 8, CDP 2800-3100 and Fig. 10, SU5-d). A recent moat is observed on the northern flank of the MEB at depths of $3100 \mathrm{~ms}(\approx 2325 \mathrm{~m})$ (Fig. 10, SU5-d). There, the mounded sediment body, observed in subunits SU5-a, SU5-b, and SU5-c on the southern flank of the MEB, persists in subunit SU5-d.

\section{Discussion}

The sedimentary units of the MEB exhibit morphological and internal reflection characteristics similar to contourite drifts, which in turn provide good archives for palaeoceanographic reconstructions. Observations of current-controlled erosional and depositional (e.g., mounded) features are interpreted in order to gain insights into the evolution of the palaeoceanographic circulation (Fig. 10).

The thickness of the Mesozoic sequences (seismic units SU1, SU2, and SU3) on the MEB directly ties to the topography of the basement, which principally rises towards the MEB, there showing isolated coneshaped local highs. In contrast, sedimentary sequences of the Cenozoic (seismic units SU4 and SU5) shape thick packages on top of the MEB while thinning towards the flanks due to erosion. We here concentrate on sedimentary features observed in seismic units SU4 and SU5 since those document the activity of oceanic currents since the Paleocene. According to Pérez-Díaz and Eagles (2017), the F/MP had reached its present depth in the Paleocene and thus the younger sedimentary deposits on the MEB represent an archive of the oceanic circulation influenced by the opening of the Drake Passage and the modifications of the Tertiary climate.

\subsection{Pre-Tertiary circulation (seismic units SU1, SU2, and SU3)}

The distinct lithological change at the Aptian-Albian boundary at DSDP Sites 327, 330, and 511, marks a change in the oceanic setting from a restricted basin to open marine conditions (Dummann et al., 2021; Shipboard Scientific Party, 1974a, 1974d, 1980a). Faunal studies at DSDP 327 and 511 suggested an increase in paleodepths from a few hundred meters in Albian to more than $1500 \mathrm{~m}$ in the Maastrichtian (Holbourn et al., 2001; Shipboard Scientific Party, 1974a). Palaeobathymeteric reconstructions of the South Atlantic support water connections between the Southern Ocean and the southern South Atlantic across the F/MP prior to Albian times (Pérez-Díaz and Eagles, 2017). Uenzelmann-Neben et al. (2017) suggested shallow (Upper Pacific Water) and intermediate (Intermediate Southern Ocean Water) water masses for the Albian and early Late Cretaceous to have entered the growing Argentine Basin.
Taking the suggested paleodepths into account, the spatially restricted observations of the erosional features in the sedimentary sequence of the Cretaceous (subunit SU2-b and unit SU3) (Fig. 6, CDPs 1500-2000 and Fig. 4, CDPs 12,000-13,000), to the west and southwest of the MEB hint at a shallow-intermediate (Upper Pacific Water) northward-flowing current. This complies with an opening of the Drake Passage for shallow water mass exchange between the Pacific and the South Atlantic in the Albian as suggested by Sewall et al. (2007) and Dummann et al. (2020). The F/MP would have played a barricading role between the Southern Ocean and the South Atlantic, except for shallowintermediate circulation at least until the late Cretaceous.

Pérez-Díaz and Eagles (2017) suggested depths of above $3000 \mathrm{~m}$ (their Fig. 3) for the southernmost part of the Argentine and Cape basins (north of the present F/MP-MEB), within the early stage of opening of the South Atlantic ( $\approx$ Aptian). Their simulation accounts for a postAlbian deep connection between the Southern Ocean and the southern South Atlantic across the Georgia Basin, confirmed by Nd isotope studies (Dummann et al., 2020). The detachment of the MEB from Africa at about the Albian may have favored the development of a deep seaway and exchange of deeper water masses (König and Jokat, 2010; Martin et al., 1982). Our observations of the erosional traces north of the MEB, in sedimentary units of the late Cretaceous (seismic units SU2-b and SU3) within depths of 4100-4700 ms (3075-3525 m) can therefore support the development of a deeper water mass entering the deepening South Atlantic from the Indian Ocean.

\subsection{Paleocene and early Eocene circulation (seismic unit SU4)}

The Paleocene and early Eocene sequences on the MEB are characterized by the increased formation of sediment drifts, moats, and erosion (Fig. 10, SU4-a and SU4-b). These contourite features indicate an enhanced circulation compared to the Cretaceous since a possible growing sediment supply can only result in contourite features if the circulation increases. These sedimentary features can be observed in three different depth intervals: a) $1800-2200 \mathrm{~m}$, b) $2400-2850 \mathrm{~m}$, and c) 3075-3525 $\mathrm{m}$. This indicates that different water masses were responsible for the formation of the contourite features.

Accompanied by erosional patches in depths of 3200-3800 ms (2400-2850 m), the presence of a Paleocene-Eocene elongated mounded drift in unit SU4 (Fig. 4, CDPs 1200-3000, Fig. 10, SU4-a and -b, and Fig. 11) points to the long-term sedimentation under the influence of a deep water mass attempting to overspill the area west of the MEB. The activity depth is similar to the present LCDW (2000-3000 m) (Arhan et al., 1999; Arhan et al., 2002; Orsi et al., 1999). We thus interpret a water mass with properties similar to LCDW (proto-LCDW) to have formed this sediment drift.

On top of the MEB, an eastward extending mounded sediment drift with an adjacent moat at depths of $2400-2500 \mathrm{~ms}(1800-1850 \mathrm{~m})$ (Fig. 5, CDPs 150-2000, Fig. 10, SU4-a and -b, and Fig. 11) is likely the result of an eastward flowing intermediate water mass. The seismic evidence of early Paleogene accentuated current-controlled deposition argues for rather quiet circulation conditions, which is consistent with steady hydrographic conditions reported by Uenzelmann-Neben et al. (2017). Their ocean-atmosphere dynamics simulations suggest domination of Antarctic Intermediate Water (AAIW), reaching velocities of 5 $\mathrm{cm} / \mathrm{s}$ in $1750 \mathrm{~m}$ water depth in the early Eocene South Atlantic sector of the Southern Ocean. AAIW or a proto-UCDW (UCDW occupies water depths of $1000-2000 \mathrm{~m}$ ) is suggested to have shaped the observed sediment drift.

Erosion extending from $2500 \mathrm{~ms}$ to $3800 \mathrm{~ms}$ (1875-2850 m depth) characterizes the northern flank of the MEB indicating the bank has acted as an obstacle, guiding both the intermediate/proto-UCDW as well as the deep water mass/proto-LCDW towards the west (Fig. 10, SU4-a and $-\mathrm{b})$. An even deeper flowing water mass shaped a drift deposit (3900-4700 ms $\cong 2925-3525 \mathrm{~m}$ depth) against the northern flank of the MEB in an east-west direction (Fig. 5, CDPs 2800-4400, Fig. 10, SU4- 


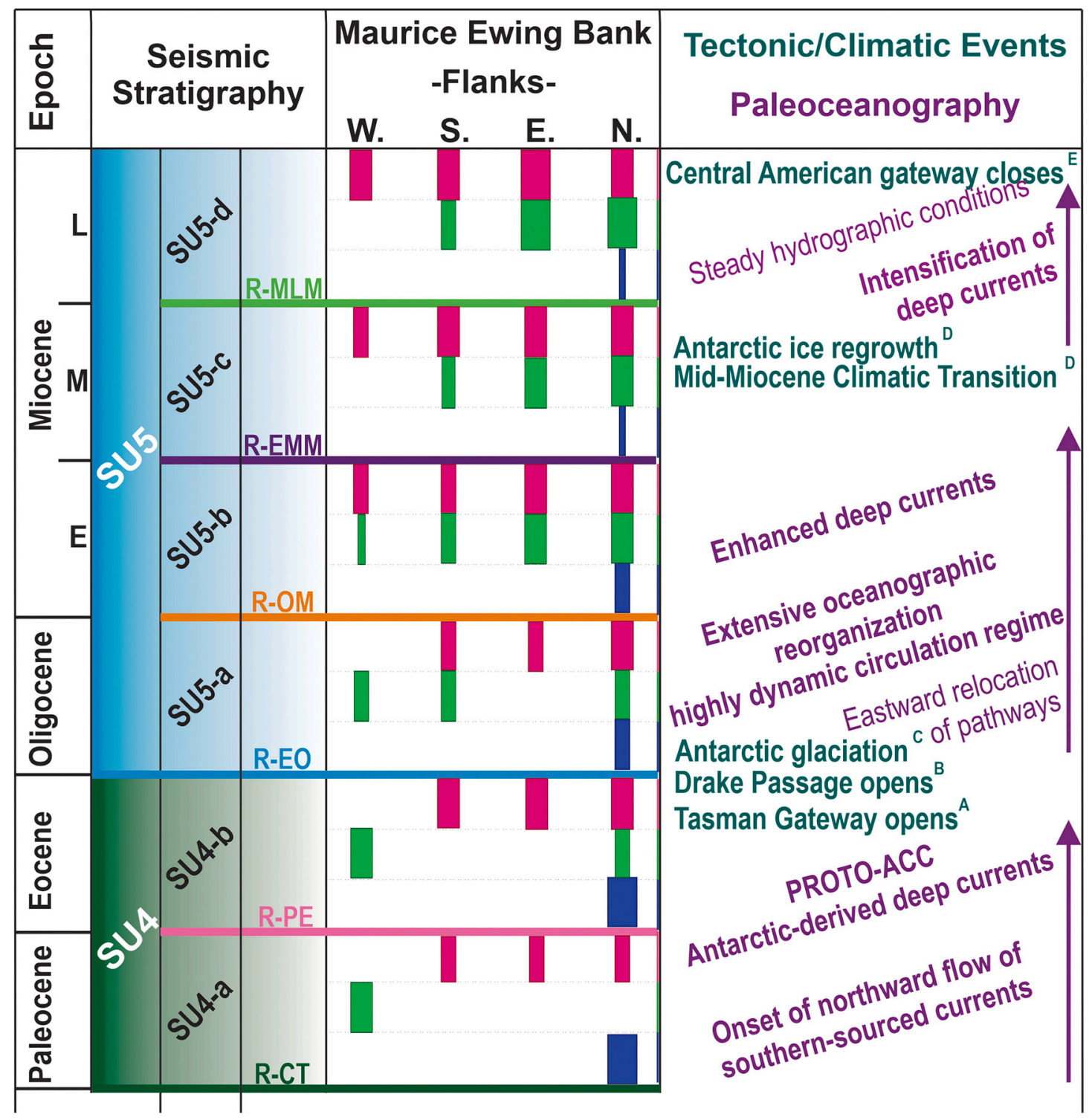

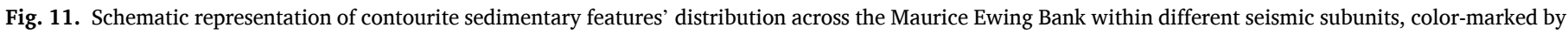

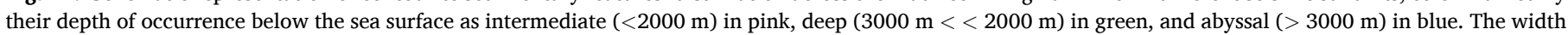

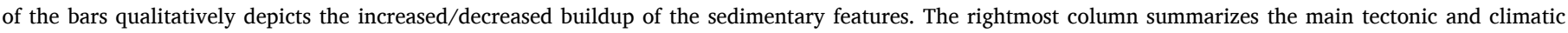

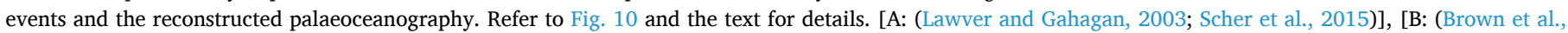

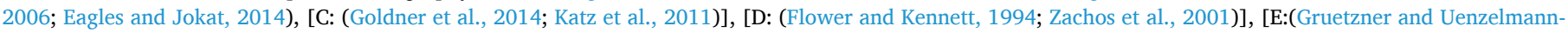

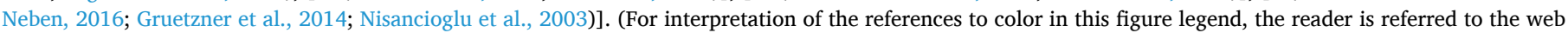
version of this article.)

a and -b, and Fig. 11). The presence of a recent moat there at the seafloor in depths of ca. $4400 \mathrm{~ms}(3300 \mathrm{~m})$ and the thin sedimentary sequences younger than Eocene (seismic unit SU5) in this northern depression hint at the continuous action of a deep-water mass at least since the early Paleogene (Fig. 5, CDPs 2500-4800). Today, Southeast Pacific Deep Water (SPDW) flows around the MEB at water depths of 2500-3500 m (Arhan et al., 2002). However, the Drake Passage was closed for deep water masses during the Paleocene and early Eocene (Eagles and Jokat, 2014). It opened for shallow water mass exchange at $\sim 41 \mathrm{Ma}$ and for deep water mass exchange at $\sim 30 \mathrm{Ma}$ (Eagles and Jokat, 2014; Scher and Martin, 2006). A precursor of SPDW thus cannot have shaped the deep sediment drift observed at the northern flank of the MEB. This deep water mass may have originated in the Southern Ocean (Fig. 11), possibly in the Indian Ocean sector (Thomas et al., 2003).

Extensive thinning and erosion, observed within sedimentary sequences of Paleocene-early Eocene (subunit SU4-a and -b) or even older (unit SU3), refer to the action of deep oceanic currents since at least the late Eocene. Erosional events of similar age are also identified via reflection seismic studies in other areas of the South Atlantic (e.g., Gruetzner and Uenzelmann-Neben, 2016; Gruetzner et al., 2012; Nicholson and Stow, 2019; Schlüter and Uenzelmann-Neben, 2008; Uenzelmann-Neben, 2001). It is thus logical to relate these extensive modifications in the oceanic setting to the tectonic events of opening of the Southern Ocean gateways during the late Eocene-early Oligocene, allowing for a circum-Antarctic full pathway and the establishment of a proto-ACC and deep water production under the expanding Antarctic ice sheets (Katz et al., 2011).

\subsection{Oligocene-Quaternary circulation (seismic unit SU5)}

The remarkable increase in current-related erosional/non-depositional features on the transition from the early Eocene (SU4-b) to the late 
Oligocene (SU5-a) points to a change towards a highly dynamic circulation regime (compare Fig. 10, SU4-b and SU5-a). Sediment drift formation in the depression north of the MEB and on the western shoulder, however, is significantly reduced (Fig. 11).

Geological records from DSDP Sites 327 and 329 relate the early Eocene-Oligocene hiatus to the opening of the Southern Ocean gateways (Shipboard Scientific Party, 1974a, 1974c). The complete opening of the Tasman gateway (Lawver and Gahagan, 2003; Scher et al., 2015) and the Drake Passage (Brown et al., 2006; Eagles and Jokat, 2014) in the Oligocene are believed to have contributed to the establishment of a proto-ACC (Scher and Martin, 2006; Uenzelmann-Neben et al., 2017). A modern four-layer ocean structure including deep and bottom waters developed in the early Oligocene as a result of this and the development of continental-scale Antarctic glaciation (Goldner et al., 2014; Katz et al., 2011).

Since the Oligocene, erosion has affected mainly two water depth ranges in the area of the MEB: a) $1575-2250 \mathrm{~m}$, and b) $2475-2975 \mathrm{~m}$. Today, these water depths correspond to the activity levels of UCDW and LCDW (Arhan et al., 1999; Arhan et al., 2002; Naveira Garabato et al., 2002). We thus suggest a proto-UCDW and a proto-LCDW to have formed the observed erosional surfaces.

An elongated mounded drift aligned with the western flank of MEB extends north-south at water depths of 2900-3300 ms (2175-2475 m) (Fig. 4, CDPs 1000-1800, Fig. 10, SU5-a, and Fig. 11). A similar water mass could be held responsible for the drift which developed coevally and within the same water depth on the southern flank of the MEB (Fig. 10, SU5-a and Fig. 11) as well as building up a sheeted drift at the northern flank (Fig. 6, CDPs 1500-2200, Fig. 10, SU5-a, and Fig. 11). Physical Oceanography studies locate a branch of the PF at the southeastern flank of the MEB. Within this eastbound branch, LCDW is constrained by the bathymetry of the MEB within a depth range of ca. 2000-3000 m flowing around it (Arhan et al., 2002; Naveira Garabato et al., 2002). From the similar circulating behavior and depth-character, we suggest a component of proto-LCDW to overspill the F/MP west of and skirting the bathymetry south and east of the MEB, causing erosion, non-deposition, and shaping the sediments since at least the late Eocene.

The formation of sediment drifts has shifted to the east mostly abandoning the maintenance of the sediment drifts shaped during the Paleocene and early Eocene (Figs. 10 and 11, compare SU4-a and -b and SU5-a to -d). We observe the build-up of a large sediment drift on top of the MEB within depths of 2200-2400 ms (1650-1800 m) until the middle Miocene (Fig. 5, CDPs 1-2000), which is further maintained until the present (Fig. 10 and Fig. 11, SU5-b to -d). The depth points to the activity of proto-UCDW. The same current could be accounted for at the northern flank of the MEB, resulting in erosional/non-depositional surfaces, leaving the Oligocene strata as the youngest sedimentary unit present (Fig. 9, CDPs 1-2200, Fig. 10, SU5-a to -d).

Numerical simulations put forward oceanic circulations dominated by an ACC for the Early Miocene (Herold et al., 2012; Von der Heydt and Dijkstra, 2006). The North Atlantic Deep Water (NADW) has been suggested to have flowed into the Pacific via the open Central American Seaway until the late Miocene ( $\sim 6 \mathrm{Ma})$ (Gruetzner et al., 2016; Gruetzner et al., 2014; Nisancioglu et al., 2003) and thus could not have shaped sediment drifts on the F/MP. The water mass shaping the sediment drifts in depths up to $2000 \mathrm{~m}$ thus can only have been protoUCDW.

The inception of the ACC is believed to have in turn favored the thermal isolation of Antarctica, leading to enlargement of the ice sheets and production of AABW by the Oligocene (Diester-Haass et al., 1996; Katz et al., 2011; Scher and Martin, 2004). We observed a transition from relative quiescence bottom water conditions in the early Eocene (subunit SU4-b) towards vigorous bottom water conditions in the middle Miocene (SU5-c) with an increase of erosion in the depression north and the area west of the MEB and enhanced sediment drift formation on the eastern MEB (Figs. 10 and 11, compare SU4-b and SU5-a to -d). This is interpreted as the pronounced deep/bottom water production due to renewed growth of Antarctic ice sheets during the mid-Miocene Climatic Transition (Flower and Kennett, 1994; Zachos et al., 2001), which agrees with a northward movement of PF towards the Argentine Basin in the Miocene proposed by Ciesielski and Wise Jr (1977). Indications for increased bottom-current activity in the middle Miocene have also been reported in other sections of the Southern Ocean (e.g., Fischer and Uenzelmann-Neben, 2018; Horn and Uenzelmann-Neben, 2015; Schlüter and Uenzelmann-Neben, 2008; Steinbrink et al., 2020; Uenzelmann-Neben, 2019b; Uenzelmann-Neben et al., 2009).

The observation of extensive erosional surfaces fully devoid of sedimentary sequences younger than late Oligocene (subunit SU5-a) within two distinct depth intervals hints at persistent and simultaneous action of a shallower and a deeper water mass since the early Miocene. These erosional patches generally lie within depths of 2200-2400 ms (1650-1750 m) (Fig. 9, CDPs 1-2200) and 2600-3100 ms (1950-2325 m) (Fig. 6, CDPs 800-1600), respectively on the top and the flanks of the MEB. In the present oceanic setting of the western South Atlantic, the PF is suggested to undergo a horizontal and vertical branching across the sill of the F/MP (Arhan et al., 2002; Naveira Garabato et al., 2002). The hydrographic data places the shallower western velocity core comprising UCDW (within depths of about 500-2000 m) northward across the F/MP, with an excursion to flow across the MEB, while a deeper eastern branch comprising LCDW lies at the southeastern flank of the MEB. An anticyclonic LCDW skirts the MEB within a depth range of ca. 2000-3000 m (Arhan et al., 2002; Naveira Garabato et al., 2002). Based on analogies in depth-character and flow path between the described erosional features and today's UCDW and LCDW, we infer the continuous action of these water masses (or precursors) in shaping the morphology of the MEB since the early Miocene along similar pathways as recognized today. This is consistent with the palaeocirculation simulation for the Miocene/Pliocene (UenzelmannNeben et al., 2017).

West of the MEB, the sediment drift formation stopped and erosion commenced in the middle Miocene within depths of $2500-2700 \mathrm{~ms}$ (1875-2025 m) (Fig. 7, CDPs 13,400-14,100, Fig. 10, and Fig. 11), documenting the impact of a proto-UCDW on sediment deposition. Ocean-atmosphere models indicate a much stronger influence of the NADW within the study area (Uenzelmann-Neben et al., 2017). On the western shoulder of the MEB, distinct erosional surfaces devoid of sediments younger than the late Oligocene-early Miocene developed (Fig. 4, CDPs 1800-2600 and Fig. 10, SU5-c) pointing towards overspill of proto-LCDW, perhaps diluted by NADW within a depth interval of 2250-2850 m, similar to today's hydrographic measurements (Arhan et al., 2002; Naveira Garabato et al., 2002).

Proto-UCDW could be held responsible for shaping the thick mounded contourite drift on the western flank of the MEB in the late Miocene within water depths of 2100-2500 ms (1575-1650 m) (Fig. 7, CDPs 13,400-14,100, Fig. 4, CDPs 1-700, Fig. 10, SU5-d, and Fig. 11). The presence of recent moats at water depths of ca. $2500 \mathrm{~ms}$ (1875 m) on top of this drift (Fig, 4, CDP $\approx 13,800$, Fig. 4, CDP $\approx 770$, and Fig. 10, SU5-d) in today's activity level of proto-UCDW (500-2000 m) endorses this interpretation.

The giant mounded drift deposit on the eastern MEB within water depths of 1700-2700 ms (1275-2025 ms) (Fig. 8 and Fig. 11), which mainly formed in middle-late Miocene times, attests to deposition at steady hydrographic conditions beneath proto-UCDW and -LCDW, bathymetrically controlled by the MEB (Fig. 10, SU5-d). Traces of water mass activity in depths $>3000 \mathrm{~m}$, which could be attributed to SPDW, can only be identified in the depression north of the MEB. During the Paleocene/early Eocene Southern Ocean Deep Water was interpreted to have flowed in from the Indian Ocean and along the northern flank of the MEB. Following the opening of a deep Drake Passage in the Oligocene, we now infer SPDW to be the shaping water mass in water depths $>3000 \mathrm{~m}$.

The DSDP drillings (Shipboard Scientific Party, 1974a, 1974b, 1974c, 1974d, 1980b) as well as the piston corings (Ciesielski and Wise 
Jr, 1977) across the MEB report only a thin veneer (less than a few meters) of Plio-Pleistocene sediments across the MEB, which is beyond the resolution of the seismic reflection data. Studies on the recovered cores, however, do report sharp biostratigraphic hiatuses within the Pliocene-Quaternary sedimentary sections (Ciesielski and Wise Jr, 1977), which have been related to the history of bottom current activity over the MEB. These include late Gilbert to mid-Gauss, Gauss-Matuyama boundary, and late Matuyama-early Brunhes time spans (Ciesielski and Weaver, 1980). However, our study cannot add to the Quaternary development.

\section{Conclusions}

The study of a set of new high-resolution seismic reflection profiles combined with information from DSDP Leg 36 Sites 327, 329, and 330 and Leg 71 Site 511 within the scheme of current-controlled sedimentation provided information on the Tertiary development of the oceanic circulation in the area of the MEB, southwestern South Atlantic (Figs. 10 and 11).

- In contrast to restricted erosion indicating a quiet circulation for the late Cretaceous, the increased formation of sediment drifts and large erosional surfaces point towards an enhanced circulation in the Paleocene/early Eocene. Three activity levels of water masses are observed and interpreted to correspond to proto-UCDW, protoLCDW, and Southern Ocean Deep Water. This provides evidence for a multi-layered ocean already in the Paleocene/early Eocene.

- Sediment drift formation bears witness to overspill of the F/MP by proto-LCDW already in the Paleocene/early Eocene. Erosion of the southern and northern flanks shows that the MEB has acted as an obstacle steering the water masses.

- A significant increase in erosional surfaces in the late Eocene/ Oligocene indicates the onset of a highly dynamic circulation regime mainly in two activity levels corresponding to proto-UCDW and proto-LCDW.

- Overspill of the F/MP appears increased in the late Eocene/Oligocene but decelerated in the early Miocene resulting in sediment drift formation. A deceleration of proto-UCDW in combination with an eastward relocation can also be observed in the early Miocene. Since the middle Miocene both water masses, proto-UCDW and -LCDW, appear to have remained uniform in intensity (within the limits of seismic resolution), maintaining both erosional features and sediment drifts but extending farther eastward.

- The study as shown attests to the strong control of the MEB's topography on the pathways of deep water masses flowing within the ACC.

\section{Data availability}

Datasets related to this article can be found at https://doi.pangaea. de/10.1594/PANGAEA.925462, https://doi.pangaea.de/10.1594/PA NGAEA.925250, https://doi.pangaea.de/10.1594/PANGAEA.925479, https://doi.pangaea.de/10.1594/PANGAEA.925478, https://doi.pang aea.de/10.1594/PANGAEA.925480, https://doi.pangaea.de/10. 1594/PANGAEA.925481, https://doi.pangaea.de/10.1594/PANGAEA. 925486, https://doi.pangaea.de/10.1594/PANGAEA.925639, https: //doi.pangaea.de/10.1594/PANGAEA.925640, https://doi.pangaea. de/10.1594/PANGAEA.925641, https://doi.pangaea.de/10.1594/PA NGAEA.925642, https://doi.pangaea.de/10.1594/PANGAEA.925643, https://doi.pangaea.de/10.1594/PANGAEA.925644, https://doi.pang aea.de/10.1594/PANGAEA.925645, https://doi.pangaea.de/10. 1594/PANGAEA.925646, https://doi.pangaea.de/10.1594/PANGAEA. 925647, https://doi.pangaea.de/10.1594/PANGAEA.925648, https: //doi.pangaea.de/10.1594/PANGAEA.925649, https://doi.pangaea. de/10.1594/PANGAEA.925650, https://doi.pangaea.de/10.1594/PA NGAEA.925651, https://doi.pangaea.de/10.1594/PANGAEA.925653, hosted at www.pangaea.de (Uenzelmann-Neben, 2020a, 2020b, 2020c, 2020d, 2020e, 2020f, 2020g, 2020h, 2020i, 2020j, 2020k, 20201, 2020m, 2020n, 2020o, 2020p, 2020q, 2020r, 2020s, 2020t, 2020u).

\section{Declaration of Competing Interest}

The authors declare that they have no known competing financial interests or personal relationships that could have appeared to influence the work reported in this paper.

\section{Acknowledgments}

We are grateful for the support of Captain R. Schmidt and his crew during cruise MSM81 with RV Maria S Merian. The data collection was funded within the core program METEOR/MERIAN provided by the Deutsche Forschungsgemeinschaft (DFG). This work was funded by the DFG under grant no. Ue 49/23. We further would like to thank the two reviewers (one anonymous and A. Tassone) and the guest editor E. Miramontes for their helpful comments, which improved the manuscript. This work used data provided by the Deep Sea Drilling Project (DSDP). The authors would like to thank Emerson E\&P Software, Emerson Automation Solutions, for providing licenses for their seismic processing and mapping software Paradigm in the scope of the Emerson Academic Program.

\section{References}

Arhan, M., Heywood, K.J., King, B.A., 1999. The deep waters from the Southern Ocean at the entry to the Argentine Basin. Deep-Sea Res. II 46, 475-499.

Arhan, M., Naveira Garabato, A.C., Heywood, K.J., Stevens, D.P., 2002. The Antarctic Circumpolar Current between the Falkland Islands and South Georgia. J. Phys. Oceanogr. 32, 1914-1931.

Barker, P.F., 1977. Correlations between sites on the eastern Falkland Plateau by means of seismic reflection profiles, Leg 36, DSDP. In: Barker, P.F., Dalziel, I., Wise Jr., S. W., et al. (Eds.), Initial Reports DSDP. U.S. Govt. Printing Office, Washington, pp. 971-990.

Barker, P.F., 2001. Scotia Sea regional tectonic evolution: implications for mantle flow and palaeocirculation. Earth Sci. Rev. 55, 1-39.

Barker, P.F., Thomas, E., 2004. Origin, signature and palaeoclimatic influence of the Antarctic Circumpolar Current. Earth Sci. Rev. 66, 143-166.

Bayer, U., 1980. The influence of sediment composition on physical properties interrelationships. In: Ludwig, W.J., Krasheninnikov, V.A., et al. (Eds.), Initial Reports DSDP. U.S. Govt. Printing Office, Washington, pp. 1111-1132.

Borrello, A.V., 1963. Fremontella inopinata n. sp. del Cámbrico de la Argentina. Ameghiniana 3, 51-55.

Brett, R., 1992. The Cretaceous-Tertiary extinction: a lethal mechanism involving anhydrite target rocks. Geochim. Cosmochim. Acta 56, 3603-3606.

Brown, B., Gaina, C., Mueller, R.D., 2006. Circum-Antarctic palaeobathymetry: illustrated examples from Cenozoic to recent times. Palaeogeogr. Paleaoclimatol. Palaeoecocol. 231, 158-168.

Chemale Jr., F., Ramos, V.A., Naipauer, M., Girelli, T.J., Vargas, M., 2018. Age of basement rocks from the Maurice Ewing Bank and the Falkland/Malvinas Plateau. Precambrian Res. 314, 28-40.

Ciesielski, P.F., Weaver, F.M., 1980. Neogene and Quaternary Paleoenvironmental history of Deep Sea Drilling Project Leg 71 Sediments, Southwest Atlantic Ocean. In: Ludwig, W.J., Krasheninnikov, V.A., et al. (Eds.), Initial Reports DSDP. U.S. Govt. Printing Office, Washington, pp. 461-477.

Ciesielski, P.F., Wise Jr., S.W., 1977. Geologic history of the Maurice Ewing Bank of the Falkland Plateau (southwest Atlantic sector of the Southern Ocean) based on piston and drill cores. Mar. Geol. 25, 175-207.

Diester-Haass, L., Robert, C., Chamley, H., 1996. The Eocene-Oligocene preglacial-glacial transition in the Atlantic sector of the Southern Ocean (ODP Site 690). Mar. Geol. 131, 123-149.

Dingle, R.V., Robson, S.H., 1992. Southwestern African Continental rise: Structural and Sedimentary Evolution. In: Poag, W., de Graciansky, C. (Eds.), Geologic Evolution of Atlantic Continental Rifts. Van Nostrand Reinhold, New York, pp. 62-75.

Du Toit, A., 1927. A Geological Comparison of South America with South Africa. Carnegie Institute of Washington Publications 381, pp. 1-157.

Du Toit, A.L., 1937. Our Wandering Continents: An Hypothesis of Continental Drifting.

Dummann, W., Steinig, S., Hofmann, P., Flögel, S., Osborne, A.H., Frank, M., Herrle, J.O., Bretschneider, L., Sheward, R.M., Wagner, T., 2020. The impact of early cretaceous gateway evolution on ocean circulation and organic carbon burial in the emerging South Atlantic and Southern Ocean basins. Earth Planet. Sci. Lett. 530, 11589.

Dummann, W., Hofmann, P., Herrle, J.O., Wennrich, V., Wagner, T., 2021. A refined model of early cretaceous South Atlantic-Southern Ocean gateway evolution based on high-resolution data from DSDP Site 511 (Falkland Plateau). Palaeogeogr. Palaeoclimatol. Palaeoecol. 110113. 
Eagles, G., Eisermann, H., 2020. The Skytrain plate and tectonic evolution of southwest Gondwana since Jurassic times. Sci. Rep. 10.

Eagles, G., Jokat, W., 2014. Tectonic reconstructions for paleobathymetry in Drake Passage. Tectonophysics 611, 28-50.

Emery, D., Myers, K., 2009. Sequence Stratigraphy. John Wiley \& Sons.

Esentia, I., Stow, D., Smillie, Z., 2018. Contourite Drifts and Associated Bedforms, Submarine Geomorphology, pp. 301-331.

Faugères, J.C., Stow, D.A.V., 2008. Chapter 14 contourite drifts: nature, evolution and controls. In: Rebesco, M., Camerlenghi, A. (Eds.), Developments in Sedimentology. Elsevier, pp. 257, 259-288.

Faugères, J.C., Stow, D.A.V., Imbert, P., Viana, A.R., 1999. Seismic Features Diagnostic of Contourite Drifts. Mar. Geol. 162, 1-38.

Fetter, A.F.H., Matano, R.P., 2008. On the origins of the variability of the Malvinas current in a global, eddy-permitting numerical simulation. J. Geophys. Res. C113.

Fischer, M.D., Uenzelmann-Neben, G., 2018. Neogene modifications of Circulation in the Northeastern African-Southern Ocean Gateway. Geochem. Geophys. Geosyst. 19, 4673-4693.

Flower, B.P., Kennett, J.P., 1994. The middle Miocene climatic transition: East Antarctic ice sheet development, deep ocean circulation and global carbon cycling. Palaeogeogr. Palaeoclimatol. Palaeoecol. 108, 537-555.

Goldner, A., Herold, N., Huber, M., 2014. Antarctic glaciation caused ocean circulation changes at the Eocene-Oligocene transition. Nature 511, 574-577.

Gruetzner, J., Uenzelmann-Neben, G., 2016. Contourite drifts as indicators of Cenozoic bottom water intensity in the eastern Agulhas Ridge area, South Atlantic. Mar. Geol. $378,350-360$.

Gruetzner, J., Uenzelmann-Neben, G., Franke, D., 2012. Variations in sediment transport at the central argentine continental margin during the Cenozoic. Geochem. Geophys. Geosyst. 13, Q10003.

Gruetzner, J., Uenzelmann-Neben, G., Franke, D., Arndt, J.E., 2014. Slow-down of Circumpolar Deepwater flow during the Late Neogene: evidence from a mudwave field at the Argentine continental slope. Geophys. Res. Lett. 41, 2070-2076, 2014GL059581.

Gruetzner, J., Uenzelmann-Neben, G., Franke, D., 2016. Evolution of the northern argentine margin during the Cenozoic controlled by bottom current dynamics and gravitational processes. Geochem. Geophys. Geosyst. 17, 3131-3149.

Gulick, S.P.S., Barton, P.J., Christeson, G.L., Morgan, J.V., McDonald, M., MendozaCervantes, K., Pearson, Z.F., Surendra, A., Urrutia-Fucugauchi, J., Vermeesch, P.M. Warner, M.R., 2008. Importance of pre-impact crustal structure for the asymmetry of the Chicxulub impact crater. Nat. Geosci. 1, 131-135.

Herold, N., Huber, M., Müller, R.D., Seton, M., 2012. Modeling the Miocene climatic optimum: Ocean circulation. Paleoceanography 27, PA1209.

Holbourn, A., Kuhnt, W., Soeding, E., 2001. Atlantic paleobathymetry, paleoproductivity and paleocirculation in the late Albian: the benthic foraminiferal record. Palaeogeogr. Palaeoclimatol. Palaeoecol. 170, 171-196.

Horn, M., Uenzelmann-Neben, G., 2015. The Deep Western Boundary current at the Bounty Trough, east of New Zealand: Indications for its activity already before the opening of the Tasmanian Gateway. Mar. Geol. 362, 60-75.

Katz, M.E., Cramer, B.S., Toggweiler, J.R., Esmay, G., Liu, C., Miller, K.G., Rosenthal, Y. Wade, B.S., Wright, J.D., 2011. Impact of Antarctic Circumpolar Current Development on late Paleogene Ocean Structure. Science 332, 1076-1079.

Koenitz, D., White, N., McCave, I.N., Hobbs, R., 2008. Internal structure of a contourite drift generated by the Antarctic Circumpolar Current. Geochem. Geophys. Geosyst. 9.

König, M., Jokat, W., 2010. Advanced insights into magmatism and volcanism of the Mozambique Ridge and Mozambique Basin in the view of new potential field data. Geophys. J. Int. 180, 158-180.

Lawver, L.A., Gahagan, L.M., 2003. Evolution of Cenozoic seaways in the circumAntarctic region. Palaeogeogr. Palaeoclimatol. Palaeoecocol. 198, 11-37.

Lonardi, A., 1974. Measurement of Chemical/Physical Properties, Vol. 36. U.S. Government Printing Office, Washington, D.C., p. 197

Lorenzo, J.M., Mutter, J.C., 1988. Seismic stratigraphy and tectonic evolution of the Falkland/Malvinas Plateau. Rev. Bras. Geosci. 18, 191-200.

Ludwig, W.J., 1983. Geologic framework of the Falkland Plateau. In: Ludwig, W.J., Krasheninnikov, V.A., et al. (Eds.), Initial Reports DSDP. U.S. Govt. Printing Office, Washington, pp. 281-293.

Marshall, J., 1994. The Falkland Islands: a key element in Gondwana paleogeography. Tectonics 13, 499-514.

Martin, A.K., Goodlad, S.W., Hartnady, C.J.H., Plessis, A.d., 1982. Cretaceous palaeopositions of the Falkland Plateau relative to southern Africa using Mesozoic seafloor spreading anomalies. Geophys. J. Int. 71, 567-579.

Mitchum Jr., R., Vail, P., Thompson III, S., 1977. Seismic Stratigraphy and Global Changes of Sea Level: Part 2. The Depositional Sequence as a Basic Unit for Stratigraphic Analysis: Section 2. Application of Seismic Reflection Configuration to Stratigraphic Interpretation.

Müller-Michaelis, A., Uenzelmann-Neben, G., Stein, R., 2013. A revised early Miocene age for the instigation of the Eirik Drift, offshore southern Greenland: evidence from high-resolution seismic reflection data. Mar. Geol. 340, 1-15.

Naveira Garabato, A.C., Heywood, K.J., Stevens, D.P., 2002. Modification and pathways of Southern Ocean Deep Waters in the Scotia Sea. Deep-Sea Res. I Oceanogr. Res. Pap. 49, 681-705.

Nicholson, U., Stow, D., 2019. Erosion and deposition beneath the Subantarctic Front since the Early Oligocene. Sci. Rep. 9, 9296.

Nielsen, T., Knutz, P.C., Kuijpers, A., Rebesco, M., Camerlenghi, A., 2008. Chapter 16 Seismic Expression of Contourite Depositional Systems, Developments in Sedimentology. Elsevier, pp. 301-321.
Nisancioglu, K.H., Raymo, M.E., Stone, P.H., 2003. Reorganization of Miocene deep water circulation in response to the shoaling of the central American Seaway. Paleoceanography 18, 1006.

Orsi, A.H., Whitworth, T., Nowlin, W.D., 1995. On the meridional extent and fronts of the Antarctic Circumpolar Current. Deep-Sea Res. I Oceanogr. Res. Pap. 42, 641-673.

Orsi, A.H., Johnson, G.C., Bullister, J.L., 1999. Circulation, mixing, and production of Antarctic Bottom Water. Prog. Oceanogr. 43, 55-109.

Pérez, L., Hernández-Molina, F.J., Esteban, F., Tassone, A., Piola, A., Maldonado, A., Preu, B., Violante, R., Lodolo, E., 2015. Erosional and depositional contourite features at the transition between the western Scotia Sea and southern South Atlantic Ocean: links with regional water-mass circulation since the Middle Miocene. GeoMar. Lett. 35, 271-288.

Pérez-Díaz, L., Eagles, G., 2017. South Atlantic paleobathymetry since Early Cretaceous. Sci. Rep. 7, 11819.

Ramos, V.A., Cingolani, C., Junior, F.C., Naipauer, M., Rapalini, A., 2017. The Malvinas (Falkland) Islands revisited: the tectonic evolution of southern Gondwana based on $\mathrm{U}-\mathrm{Pb}$ and Lu-Hf detrital zircon isotopes in the Paleozoic cover. J. S. Am. Earth Sci. 76, 320-345.

Rebesco, M., Camerlenghi, A., Volpi, V., Neagu, C., Accettella, D., Lindberg, B., Cova, A., Zgur, F., Magico, P., 2007. Interaction of processes and importance of contourites: Insights from the detailed morphology of sediment Drift 7, Antarctica. In: Viana, A., Rebesco, M. (Eds.), Economic and Palaeoceanographic Significance of Contourite Deposits. Geological Society of London. Special Publication, London, pp. 95-110.

Rebesco, M., Hernández-Molina, F.J., Van Rooij, D., Wåhlin, A., 2014. Contourites and associated sediments controlled by deep-water circulation processes: State-of-the-art and future considerations. Mar. Geol. 352, 111-154.

Scher, H.D., Martin, E.E., 2004. Circulation in the Southern Ocean during the Paleogene inferred from neodymium isotopes. Earth Planet. Sci. Lett. 228, 391-405.

Scher, H.D., Martin, E.E., 2006. Timing and climatic consequences of the opening of Drake Passage. Science 312, 428-430.

Scher, H.D., Whittaker, J.M., Williams, S.E., Latimer, J.C., Kordesch, W.E.C., Delaney, M. L., 2015. Onset of Antarctic Circumpolar current 30 million years ago as Tasmanian Gateway aligned with westerlies. Nature 523, 580-583.

Schlüter, P., Uenzelmann-Neben, G., 2008. Indications for bottom current activity since Eocene times: the climate and ocean gateway archive of the Transkei Basin, South Africa. Glob. Planet. Chang. 60, 416-428.

Schulte, P., Alegret, L., Arenillas, I., Arz, J.A., Barton, P.J., Bown, P.R., Bralower, T.J., Christeson, G.L., Claeys, P., Cockell, C.S., Collins, G.S., Deutsch, A., Goldin, T.J., Goto, K., Grajales-Nishimura, J.M., Grieve, R.A.F., Gulick, S.P.S., Johnson, K.R., Kiessling, W., Koeberl, C., Kring, D.A., MacLeod, K.G., Matsui, T., Melosh, J., Montanari, A., Morgan, J.V., Neal, C.R., Nichols, D.J., Norris, R.D., Pierazzo, E., Ravizza, G., Rebolledo-Vieyra, M., Reimold, W.U., Robin, E., Salge, T., Speijer, R.P., Sweet, A.R., Urrutia-Fucugauchi, J., Vajda, V., Whalen, M.T., Willumsen, P.S., 2010. The Chicxulub Asteroid Impact and Mass Extinction at the Cretaceous-Paleogene Boundary. Science 327, 1214-1218.

Sewall, J.O., van de Wal, R.S.W., van der Zwan, K., van Oosterhout, C., Dijkstra, H.A., Scotese, C.R., 2007. Climate model boundary conditions for four cretaceous time slices. Clim. Past 3, 647-657.

Shipboard Scientific Party, 1974a. Site 327. In: Barker, P.F., Dalziel, I., Wise Jr., S.W. (Eds.), Initail Reports DSDP. US Government Printing, Washington, pp. 27-86.

Shipboard Scientific Party, 1974b. Site 328. In: Barker, P.F., Dalziel, I., Wise Jr., S.W. (Eds.), Initail Reports DSDP. US Government Printing, Washington, pp. 87-141.

Shipboard Scientific Party, 1974c. Site 329. In: Barker, P.F., Dalziel, I., Wise Jr., S.W. (Eds.), Initial Reports DSDP. US Government Printing, Washington, pp. 143-206.

Shipboard Scientific Party, 1974d. Site 330. In: Barker, P.F., Dalziel, I., Wise Jr., S.W. (Eds.), Initail Reports DSDP. US Government Printing, Washington, pp. 207-257.

Shipboard Scientific Party, 1977. Evolution of the Southwestern Atlantic Ocean Basin: Results of Leg 36, Deep Sea Drilling Project. In: Barker, P.F., Dalziel, I., Wise Jr., S. W., et al. (Eds.), Initial Reports DSDP. U.S. Govt. Printing Office, Washington, pp. 993-1014.

Shipboard Scientific Party, 1980a. Site 511. In: Ludwig, W.J., Krasheninnikov, V.A., et al. (Eds.), Initial Reports DSDP. U.S. Govt. Printing Office, Washington, pp. 21-109.

Shipboard Scientific Party, 1980b. Site 512. In: Ludwig, W.J., Krasheninnikov, V.A., et al. (Eds.), Initial Reports DSDP. U.S. Govt. Printing Office, Washington.

Smith, W.H.S., Sandwell, D.T., 1997. Global sea floor topography from satellite altimetry and ship depth soundings. Science 277, 1956-1962.

Sokolov, S., Rintoul, S.R., 2009. Circumpolar structure and distribution of the Antarctic Circumpolar Current fronts: 1. Mean circumpolar paths. J. Geophys. Res. 114.

Steinbrink, L., Gohl, K., Riefstahl, F., Davy, B., Carter, L., 2020. Late cretaceous to recent ocean-bottom currents in the SW Pacific Gateway, southeastern Chatham rise, New Zealand. Palaeogeogr. Palaeoclimatol. Palaeoecol. 546, 109633.

Stone, P., Kimbell, G., Richards, P., 2009. Rotation of the Falklands microplate reassessed after recognition of discrete Jurassic and cretaceous dyke swarms. Pet. Geosci. 15, 279-287.

Stow, D.A.V., Faugères, J.-C., Howe, J.A., Pudsey, C.J., Viana, A.R., 2002. Bottom currents, contourites and deep-sea sediment drifts: Current state-of-the-art. In: Stow, D.A.V., Pudsey, C.J., Howe, J.A., Faugeres, J.-C., Viana, A.R. (Eds.), DeepWater Contourite Systems: Modern Drifts and Ancient Series. Geological Society of London, London, pp. 7-20.

Taylor, G.K., Shaw, J., 1989. The Falkland Islands: New palaeomagnetic data and their origin as a displaced terrane from southern Africa. In: Deep Structure and Past Kinematics of Accreted Terranes 50, pp. 59-72.

Thomas, D.J., Bralower, T.J., Jones, C.E., 2003. Neodymium isotopic reconstruction of late Paleocene-early Eocene thermohaline circulation. Earth Planet. Sci. Lett. 209, 309-322. 
Thompson, R., 1977. Mesozoic Sedimentation on the Eastern Falkland Plateau. Thomson, K., 1998. When did the Falklands rotate? Mar. Pet. Geol. 15, 723-736.

Timofeev, P.P., Renngarten, N.V., Rateev, M.A., 1980. Lithologic facies and clay minera assemblages in Mesozoic and Cenozoic sediments recovered by DEEP Sea Drilling Project LEG 71 in the South Atlantic. In: Ludwig, W.J., Krasheninnikov, V.A., et al (Eds.), Initial Reports DSDP. U.S. Govt. Printing Office, Washington, pp. 377-388.

Uenzelmann-Neben, G., 2001. Seismic characteristics of sediment drifts: an example from the Agulhas Plateau, southwest Indian Ocean. Mar. Geophys. Res. 22, 323-343.

Uenzelmann-Neben, G., 2019a. Onset and modifications in intensity and pathways of water mass exchange between the Southeast Pacific and the South Atlantic with focus on the Falkland Plateau, Northern Scotia Ridge and the West Georgia Basin, Cruise No. MSM81, February 2 2019-March 15 2019. In: Valparaiso (Chile) Montevideo (Uruguay, MARIA S. MERIAN-Berichte, Bonn), p. 30.

Uenzelmann-Neben, G., 2019b. Variations in ice-sheet dynamics along the Amundsen Sea and Bellingshausen Sea West Antarctic Ice Sheet margin. GSA Bull. 131, 479-498.

Uenzelmann-Neben, G., 2020a. Falkland Plateau Sediment Drift, Seismic Reflection Profile AWI-20190001 (PANGAEA).

Uenzelmann-Neben, G., 2020b. Falkland Plateau Sediment Drift, Seismic Reflection Profile AWI-20190002 (PANGAEA).

Uenzelmann-Neben, G., 2020c. Falkland Plateau Sediment Drift, Seismic Reflection Profile AWI-20190012 (PANGAEA).

Uenzelmann-Neben, G., 2020d. Falkland Plateau Sediment Drift, Seismic Reflection Profile AWI-20190013 (PANGAEA).

Uenzelmann-Neben, G., 2020e. Falkland Plateau Sediment Drift, Seismic Reflection Profile AWI-20190015 (PANGAEA).

Uenzelmann-Neben, G., 2020f. Falkland Plateau Sediment Drift, Seismic Reflection Profile AWI-20190016 (PANGAEA).

Uenzelmann-Neben, G., 2020g. Falkland Plateau Sediment Drift, Seismic Reflection Profile AWI-20190017 (PANGAEA).

Uenzelmann-Neben, G., 2020h. Falkland Plateau Sediment Drift, Seismic Reflection Profile AWI-20190018 (PANGAEA).

Uenzelmann-Neben, G., 2020i. Falkland Plateau Sediment Drift, Seismic Reflection Profile AWI-20190019 (PANGAEA).

Uenzelmann-Neben, G., 2020j. Falkland Plateau Sediment Drift, Seismic Reflection Profile AWI-20190020 (PANGAEA).

Uenzelmann-Neben, G., 2020k. Falkland Plateau Sediment Drift, Seismic Reflection Profile AWI-20190021 (PANGAEA).
Uenzelmann-Neben, G., 20201. Falkland Plateau Sediment Drift, Seismic Reflection Profile AWI-20190022 (PANGAEA).

Uenzelmann-Neben, G., 2020m. Falkland Plateau Sediment Drift, Seismic Reflection Profile AWI-20190023 (PANGAEA).

Uenzelmann-Neben, G., 2020n. Falkland Plateau Sediment Drift, Seismic Reflection Profile AWI-20190024 (PANGAEA).

Uenzelmann-Neben, G., 2020o. Falkland Plateau Sediment Drift, Seismic Reflection Profile AWI-20190025 (PANGAEA).

Uenzelmann-Neben, G., 2020p. Falkland Plateau Sediment Drift, Seismic Reflection Profile AWI-20190026 (PANGAEA).

Uenzelmann-Neben, G., 2020q. Falkland Plateau Sediment Drift, Seismic Reflection Profile AWI-20190027 (PANGAEA).

Uenzelmann-Neben, G., 2020r. Falkland Plateau Sediment Drift, Seismic Reflection Profile AWI-20190028 (PANGAEA).

Uenzelmann-Neben, G., 2020s. Falkland Plateau Sediment Drift, Seismic Reflection Profile AWI-20190029 (PANGAEA).

Uenzelmann-Neben, G., 2020t. Falkland Plateau Sediment Drift, Seismic Reflection Profile AWI-20190030 (PANGAEA).

Uenzelmann-Neben, G., 2020u. Falkland Plateau Sediment Drift, Seismic Reflection Profile AWI-20200014 (PANGAEA).

Uenzelmann-Neben, G., Schlüter, P., Weigelt, E., 2007. Cenozoic oceanic circulation within the south African gateway: indications from seismic stratigraphy. S. Afr. J. Geol. 110, 275-294.

Uenzelmann-Neben, G., Grobys, J.W.G., Gohl, K., Barker, D., 2009. Neogene sediment structures in Bounty Trough, eastern New Zealand: influence of magmatic and oceanic current activity. Geol. Soc. Am. Bull. 121, 134-149.

Uenzelmann-Neben, G., Weber, T., Grützner, J., Thomas, M., 2017. Transition from the cretaceous ocean to Cenozoic circulation in the western South Atlantic - A twofold reconstruction. Tectonophysics $716,225-240$.

Vail, P., Mitchum Jr., R., Thompson III, S., 1977. Seismic Stratigraphy and Global Changes of Sea Level: Part 4. Global Cycles of Relative Changes of Sea Level.: Section 2. Application of Seismic Reflection Configuration to Stratigraphic Interpretation.

Von der Heydt, A., Dijkstra, H.A., 2006. Effect of ocean gateways on the global ocean circulation in the late Oligocene and early Miocene. Paleoceanography 21.

Worsley, T., 1974. The Cretaceous-Tertiary Boundary Event in the Ocean.

Yilmaz, O., 2001. Seismic Data Analysis. Society of Exploration Geophysicists, Tulsa.

Zachos, J.C., Pagani, M., Sloan, L., Thomas, E., Billups, K., 2001. Trends, rhythms, and aberrations in Global climate 65 Ma to present. Science 292, 686-693. 